\title{
7. SEDIMENTARY FRAMEWORK OF THE BELLINGSHAUSEN BASIN FROM SEISMIC PROFILER DATA ${ }^{1}$
}

\author{
Brian E. Tucholke and Robert E. Houtz, \\ Lamont-Doherty Geological Observatory of Columbia University, Palisades, New York
}

\begin{abstract}
Alice had not the slightest idea what Latitude was, or Longitude either, but thought they were nice grand words to say.
\end{abstract}

-Lewis Carroll

\section{INTRODUCTION}

Only limited research has been devoted to the morphology, sediment distribution, and sedimentary processes in the Bellingshausen Basin. Based primarily on early Eltanin data, M. Ewing et al. (1968) described the thick sediment apron extending north from Antarctica between the Antarctic Peninsula and about $140^{\circ} \mathrm{W}$. They called this sediment cover the Bellingshausen sediment body. Houtz et al. (1973) mapped sediment thickness adjacent to Antarctica west of $60^{\circ} \mathrm{W}$, and their data suggested that the Bellingshausen sediment body is continuous with thick Antarctic continental-margin sediments throughout the western Pacific and Indian Ocean sectors of Antarctic waters. These studies and those of M. Ewing et al. (1969) and J. Ewing et al. (1971) showed very thin sediments between about $57^{\circ}$ and $60^{\circ} \mathrm{S}$ in the Bellingshausen Basin, in the Drake Passage, and on the southern side of the passage adjacent to the Antarctic Peninsula. Deductions about sedimentary processes which were included in these papers are discussed in the appropriate sections below.

This report has a threefold purpose: (1) to delineate the physiographic provinces and bathymetry of the Bellingshausen Basin where the Leg 35 sites were drilled, (2) to outline sediment distribution and acoustic provinces as inferred from seismic profiler data, and (3) to discuss the evolution of terrigenous sedimentation processes in the basin through the combined interpretation of tectonic processes, acoustic records, and the sediment data from drill cores.

\section{SUMMARY OF CRUSTAL EVOLUTION}

The plate tectonic history and basement structure of this region are discussed by Herron and Tucholke (this volume). However, the ages and tectonic pattern of Layer 2 are briefly recapitulated here as a framework for the ensuing discussions.

Magnetic anomalies indicate that oceanic crust in the Bellingshausen Basin was created by two subparallel, north to northeast-trending spreading ridges (Figure 1). Crust at least as old as anomaly 32 (76 m.y.) in the central Bellingshausen Basin was generated by the PacificAntarctic Ridge which presently lies to the northwest.

'Contribution No. 2203 of the Lamont-Doherty Geologic Observatory.
The spreading ridge to the southeast (the Aluk Ridge) became active no later than about 64 m.y. ago (anomaly 26 ), and it has been progressively subducted from west to east beneath West Antarctica and the Antarctic Peninsula; magnetic anomalies indicate that only the northwest flank of the Aluk Ridge now remains seaward of the Antarctic continental slope.

Several fracture zones appear in the flank of the Aluk Ridge, and they presently extend roughly northwest from the base of the continental slope (Figure 1). The Tula Fracture Zone extends northwest from the slope at $67^{\circ} \mathrm{S}, 73^{\circ} \mathrm{W}$, and it separates old (pre-Eocene) crust on the southwest from younger, more recently underthrust crust (Miocene) on the northeast. A second major fracture zone (Hero Fracture Zone) extends northwest from about $62^{\circ} \mathrm{S}, 65^{\circ} \mathrm{W}$ and separates pre-anomaly 6 crust (early Miocene) on the southwest from MiocenePliocene crust on the northeast. There is a rugged northeast-trending structural ridge (the Palmer Ridge) between these two fracture zones and about $400 \mathrm{~km}$ seaward of the shelf break. In the Drake Passage a northeast-trending spreading ridge is indicated by magnetic anomalies between the Hero and Shackleton Fracture zones (Barker, 1971). Submarine seismic activity (Barazangi and Dorman, 1969), the presence of the South Shetland Trench, and recent volcanism to the south (Deception Island; Baker et al., 1969) suggest that spreading may still be occurring, although the youngest identifiable anomaly at the ridge crest was formed about 4 m.y. ago.

The major fracture zone associated with the PacificAntarctic Ridge is the Eltanin Fracture Zone. It consists of a pair of fractures extending east-southeast into the Bellingshausen Basin and offsetting the ocean crust in a right lateral sense (Figure 1). Other fracture zones defined by bathymetry, seismic profiler data and magnetic anomaly offsets are depicted in Figure 1. There is a general correlation between age and depth of the crust throughout the Bellingshausen Basin (see Herron and Tucholke, this volume).

\section{BATHYMETRY AND PHYSIOGRAPHIC PROVINCES}

The bathymetric map in the cover pocket (Figure 2) is based on the soundings available at Lamont-Doherty Geological Observatory and includes those of Glomar Challenger Leg 35 (Figure 3). North of $67^{\circ} \mathrm{S}$ and west of 


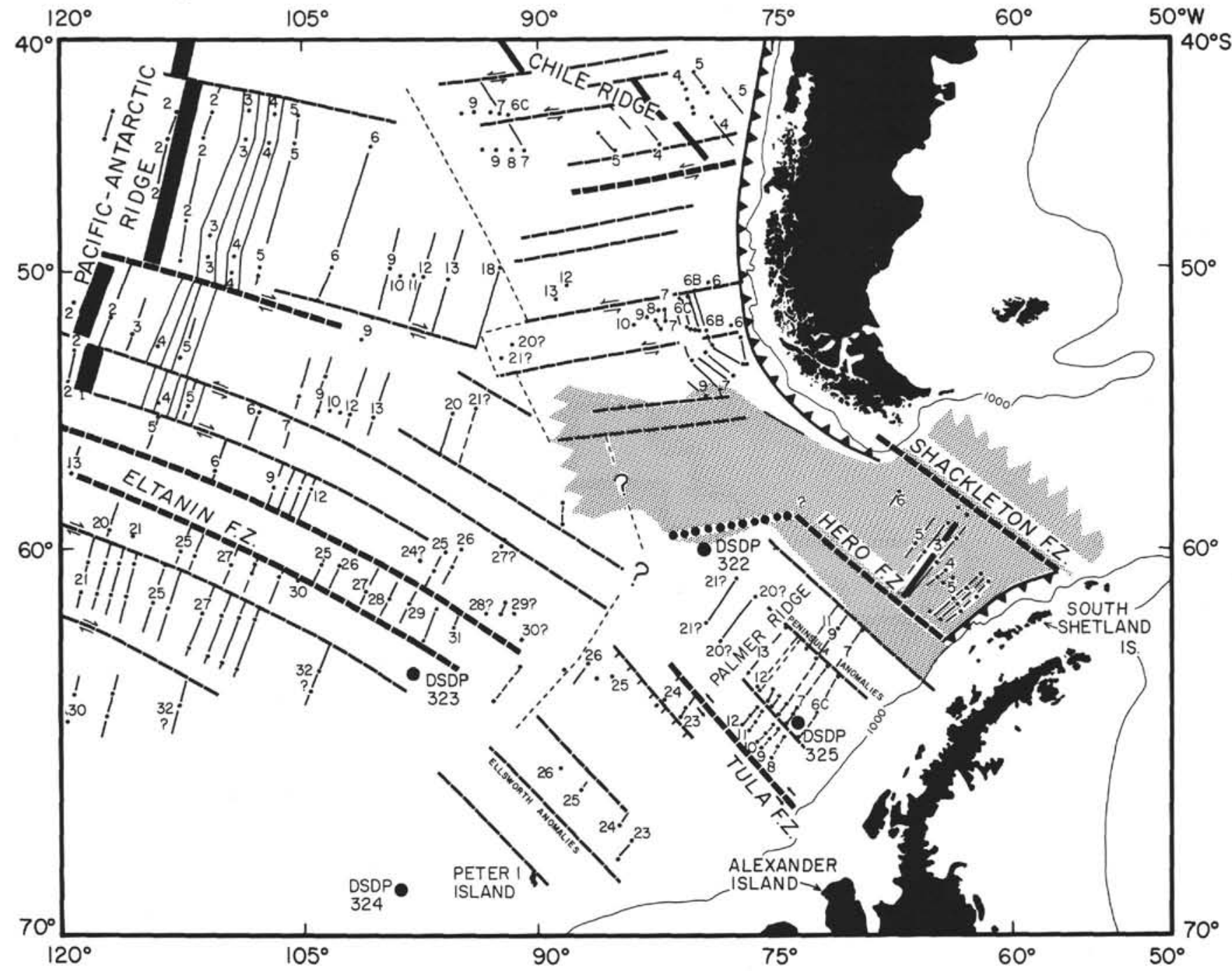

Figure 1. Magnetic and tectonic patterns of the southeastern Pacific. Axes of spreading ridges are shown by heavy solid lines, magnetic lineations by light lines, fracture zones by dashed lines, and trenches by lines with triangles. Shading shows a region of extremely rugged crust (eastern and western limits not indicated).

$70^{\circ} \mathrm{W}$ the map is modified from Mammerickx et al. (1974a, b) using soundings from Vema 16 and 18, Conrad 15, and Challenger 35. Early Eltanin soundings (cruises 5, 10, and 11) were also utilized in areas of smooth to moderate topography. In regions of rough topography, such as in the northeastern corner of the map, the early soundings were not used because the navigational inaccuracies tend to confuse rather than clarify topographic patterns. For the reader who wishes to determine depths in corrected meters, areas 26 through 29 of Matthew's (1939) tables are included in the region covered by the bathymetric map.

The physiographic provinces of this region are shown in Figure 4 and are described briefly below, proceeding seaward from the Antarctic continent.

\section{Continental Shelf and Slope}

Precision echo-sounding profiles (Vema 18 and Eltanin 5, 42, and 43) across the seaward portion of the Antarctic continental shelf (Figures 3 and 5) indicate that the surface of the shelf is irregular and, as is frequently observed adjacent to ice-covered continents, much deeper than typical continental shelves in the world oceans. The average depth of the outer shelf appears to decrease irregularly from about $300 \mathrm{fm}$ ( 545 $\mathrm{m})$ in the southwest to roughly $230 \mathrm{fm}(417 \mathrm{~m})$ on the northeast side of the Tula Fracture Zone. The surface irregularities, U-shaped glacial-type valleys (profile D, Figure 5), and the apparent truncation of inclined beds observed in profiler records (Figure 6) are characteristic of glaciated shelves.

The seaward edge of the shelf is commonly slightly elevated, forming a "lip" or sill. The shelf break itself is usually sharp and lies at depths less than $230 \mathrm{fm}(417 \mathrm{~m})$ in the northeastern region; however, the shelf break is as much as $70 \mathrm{fm}(127 \mathrm{~m})$ deeper in the southwest.

The continental slope is extremely steep along the northeastern margin, with gradients as high as $1: 5\left(11^{\circ}\right)$. The base of the slope occurs near $1600 \mathrm{fm}$ where the seafloor gradient decreases to less than 1:40. Southwest of the Tula Fracture Zone, an Eltanin 42 crossing indicates that the slope is gentler, with gradients of about $1: 12$ to $1: 21\left(3^{\circ}-4^{\circ}\right)$; in this area the base of the slope lies at $1400-1600 \mathrm{fm}$.

Unfortunately, most of the ship tracks approaching the shelf run perpendicular to the contours so it is not 


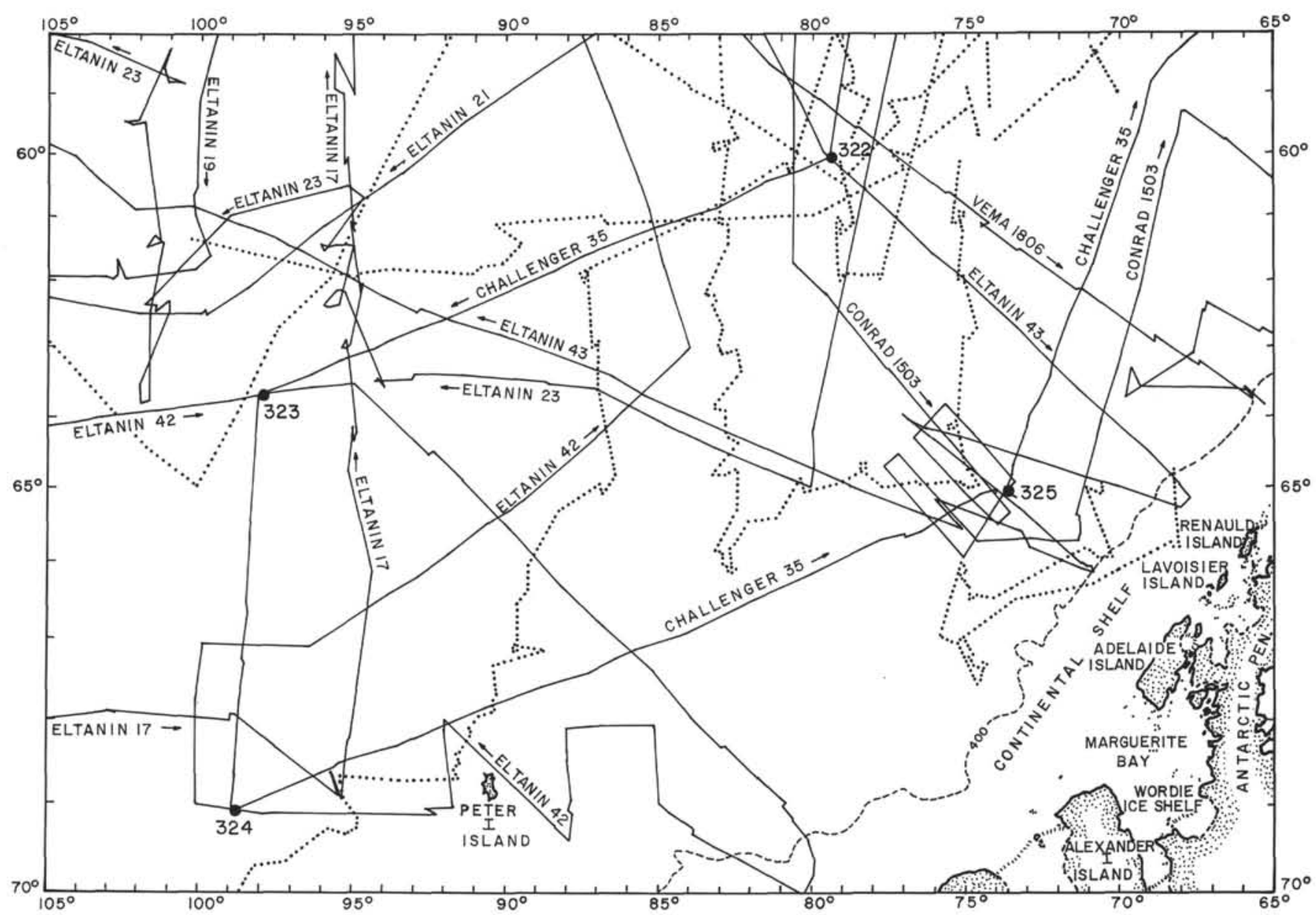

Figure 3. Track control in the Bellingshausen Basin. Solid tracks have seismic profiler and echo sounding data; dotted tracks have echo sounding only. Leg 35 drill sites are indicated.

possible to determine whether the continental slope is deeply incised by submarine canyons. However, the presence of major channels on the upper continental rise (Figure 2) implies the presence of canyons in the adjacent slope.

\section{Continental Rise}

The continental rise is well developed along the entire Antarctic margin studied except northeast of the Hero Fracture Zone where rugged abyssal hills occur seaward of the South Shetland Trench (J. Ewing et al., 1971). Between the Hero and Tula Fracture zones the rise is interrupted by the high basement relief of the northeasttrending Palmer Ridge (Figure 4). The continental rise landward of the ridge has an average gradient of 1:300; below, it has a gradient closely approaching that of the abyssal plain (about 1:900) out to about $2650 \mathrm{fm}$. Irregular basement peaks of the Palmer Ridge intermittently protrude through sediments of the central part of the rise, creating locally rough topography. Southwest of the Tula Fracture Zone, the continental rise extends to about the 2500 -fm contour, and its surface gradient decreases steadily seaward.

The central and upper continental rise is crossed by numerous channels, but the channels are best developed in the western part of the area studied. Few ship tracks cross the lower rise, but those that do cross suggest infrequent and poorly developed channels.
One noteworthy feature near the lower rise/abyssal plain boundary is a tablemount or guyot due north of Peter I Island. This guyot was crossed twice on Eltanin cruise 42 , and the shallowest depth recorded on its relatively level top is $216 \mathrm{fm}(391 \mathrm{~m})$. Several other seamounts interrupt the continental rise (Figure 4), but none of these is flat-topped nor does any rise to such shallow depths.

\section{Abyssal Plain and Abyssal Hills}

The Bellingshausen Abyssal Plain, limited by definition to gradients less than 1:1000 (Heezen et al., 1954), is developed below depths of about $2500 \mathrm{fm}(4667 \mathrm{~m})$ in the west to $2650 \mathrm{fm}(4956 \mathrm{~m})$ in the east. The abyssal plain ends abruptly just east of Site 322 . The northern boundary of the province is irregular because abyssal plain sediments have ponded against the rough abyssalhill topography and into the fracture zones. A series of possibly interconnected sediment ponds with variable gradients has been created in this region, apparently as a consequence of sediment overflowing small sills and spilling into progressively deeper depressions.

The main part of the abyssal plain is interrupted in several places by ridges and seamounts which have affected sediment dispersal patterns and have created complex local topography in the adjacent ponded sediment. A few minor channels are observed in these areas (Figure 4). 


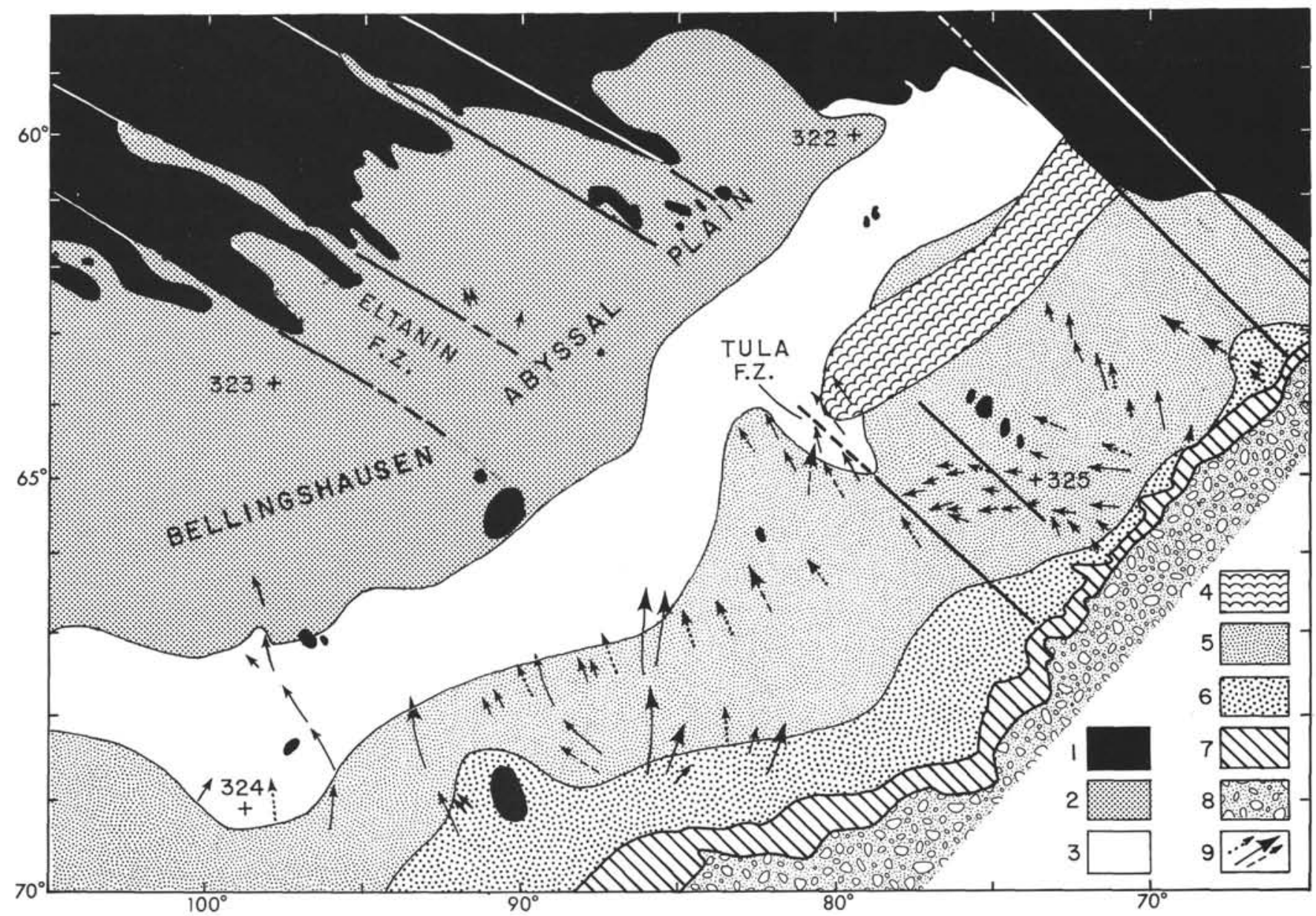

Figure 4. Physiographic and seismic-profiler acoustic provinces of the Bellingshausen Basin. (1) Abyssal hills province and seamounts. (2) Bellingshausen Abyssal Plain - flat, highly reflective and laminated sediment. (3) Lower continental rise gently sloping, moderately laminated sediment. (4) Palmer Ridge - basement ridge partially covered by ponded, pelagic, and current-deposited sediment. (5) Central continental rise - finely-laminated sediment. (6) Upper continental rise poorly laminated, highly reflective sediment. (7) Continental slope. (8) Continental shelf. (9) Deep-sea channels: dotted arrows, buried; solid arrows, active; dashed arrows, choked or inactive. Known fracture zones are indicated by solid lines and their inferred extensions by dashed lines.

The abyssal hills province is typically a rugged and topographically complex region similar to other old ridge-flank areas (Sclater et al., 1971), but the region just north of Site 322 is especially irregular. The deepest areas within the abyssal hills province are generally in the fracture zones; the maximum depth recorded within the area of Figure 2 is $3094 \mathrm{fm}(5806 \mathrm{~m})$ just northeast of Site 322 , but we are uncertain that a major fracture zone extends through this depression.

\section{SEDIMENT DISTRIBUTION}

The distribution and thickness of sediment are clearly related to the age, geographic position, and tectonic evolution of the basement crust in the Bellingshausen Basin (Figure 7). It is also apparent that the sediment in the basin has been derived primarily from the Antarctic continent and deposited in a wedge thinning seaward from the base of the Antarctic continental slope. The rugged abyssal hills to the north have blocked sediment derived from South America.

The zone of thinnest sediments $(<0.1 \mathrm{sec})$ covers the old crust of the abyssal hills province, the young crust east of the Hero Fracture Zone, and portions of the Palmer Ridge. Continental rise and abyssal plain sediments are much thinner northeast of the Tula Fracture Zone than they are to the southwest. This may be attributed to the more recent cessation of underthrusting in the northeastern region where subduction continued until at least early Miocene time. The pre-Miocene trench and Palmer Ridge may have acted as barriers to sediment transport to the deep basin, and at present the Palmer Ridge still blocks much downslope transport in the central part of the area.

Subduction is inferred from magnetic anomalies to have ceased about $15 \mathrm{~m} . y$. earlier southwest of the Tula Fracture Zone than to the northeast. Thus the continental rise began to develop much earlier along the southwestern margin, and sediments are thickest there. 


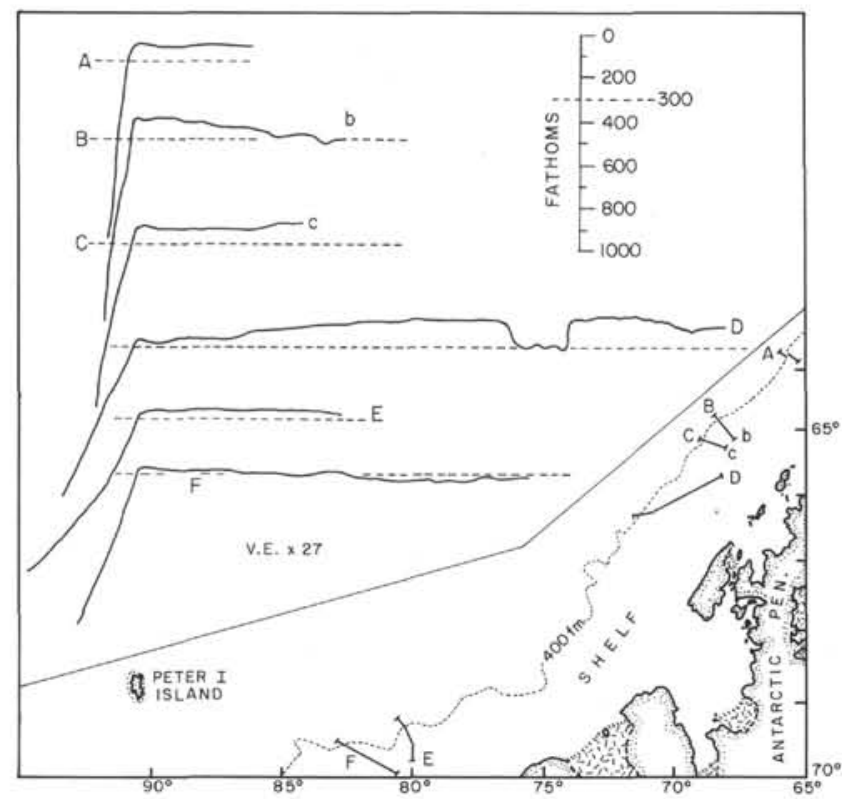

Figure 5. Echo-sounding profiles across the outer shelf and upper slope.
The extension of a tongue of relatively thick sediments northeastward from this area toward Site 322 suggests that some of the earliest sediments deposited seaward of the Palmer Ridge were derived from the continental margin southwest of the Tula Fracture Zone.

Major anomalies in sediment thickness are also associated with the Eltanin Fracture Zone. The northern fracture is a deep cleft commonly filled with more than one second of sediment, and the southern fracture is also locally filled with more than $0.5 \mathrm{sec}$ of sediment (Figure 8). East of about $93^{\circ} \mathrm{W}$, however, neither of the fractures is easily distinguishable as a cleft in acoustic basement. Here they are bounded by broad, irregular basement ridges, and the crustal fracture, if present, is usually masked by either highly reflective sediment or basalt fill. These subsurface features are indicated by the thin sediment cover over the southern fracture to at least $66^{\circ} \mathrm{S}$.

\section{SEDIMENT VELOCITIES}

The results of 45 sonobuoy measurements recorded over the varied physiographic provinces of the Bellingshausen Basin appear in Figure 9 as plots of sound velocity (averaged over individual layers) versus

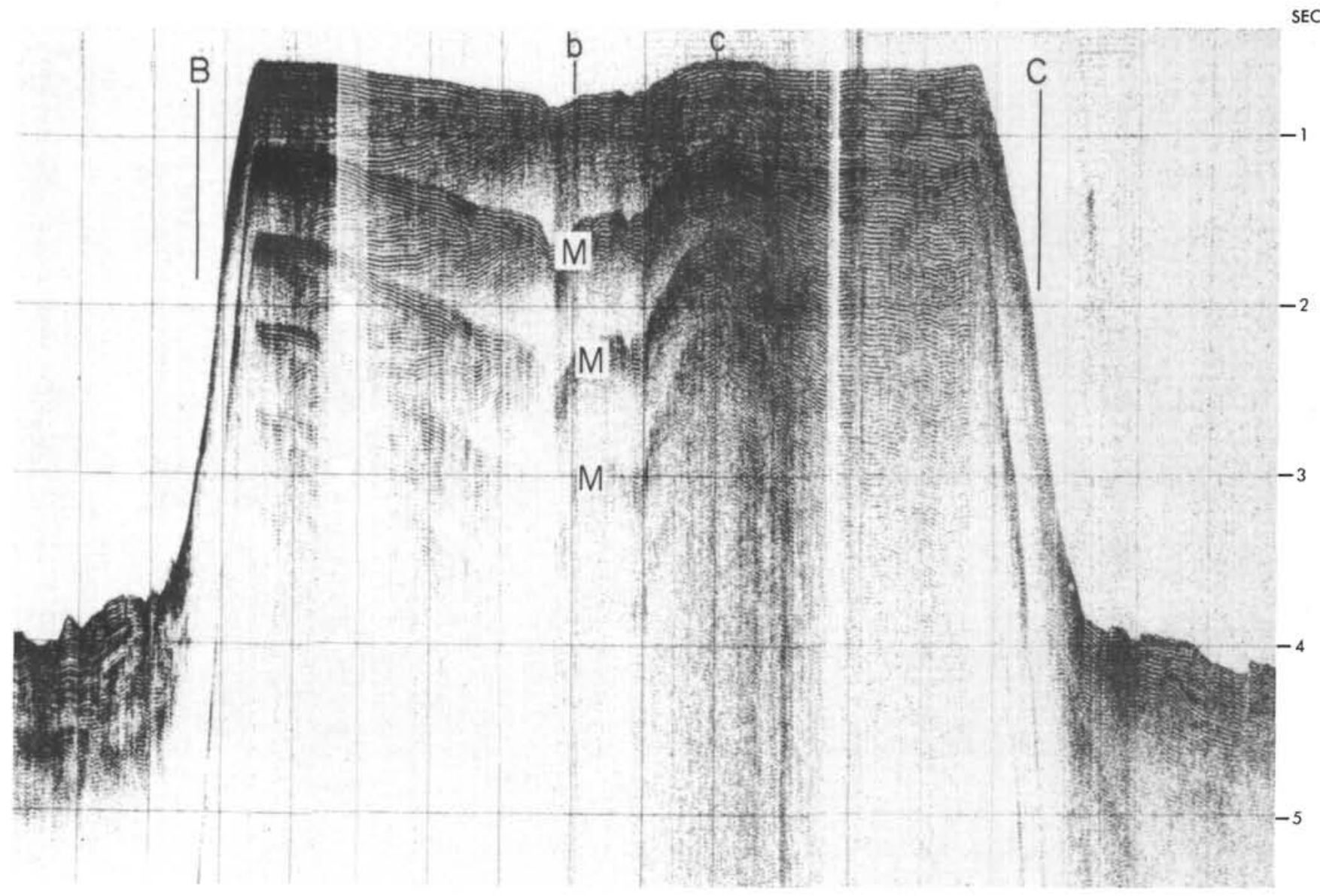

Figure 6. Eltanin 43 seismic profiler record onto and off the continental shelf in the eastern Bellingshausen Basin. Note the apparent truncation of dipping layers in the shelf sediments. Multiple reflections are indicated by M. For location see Figure 5 . 


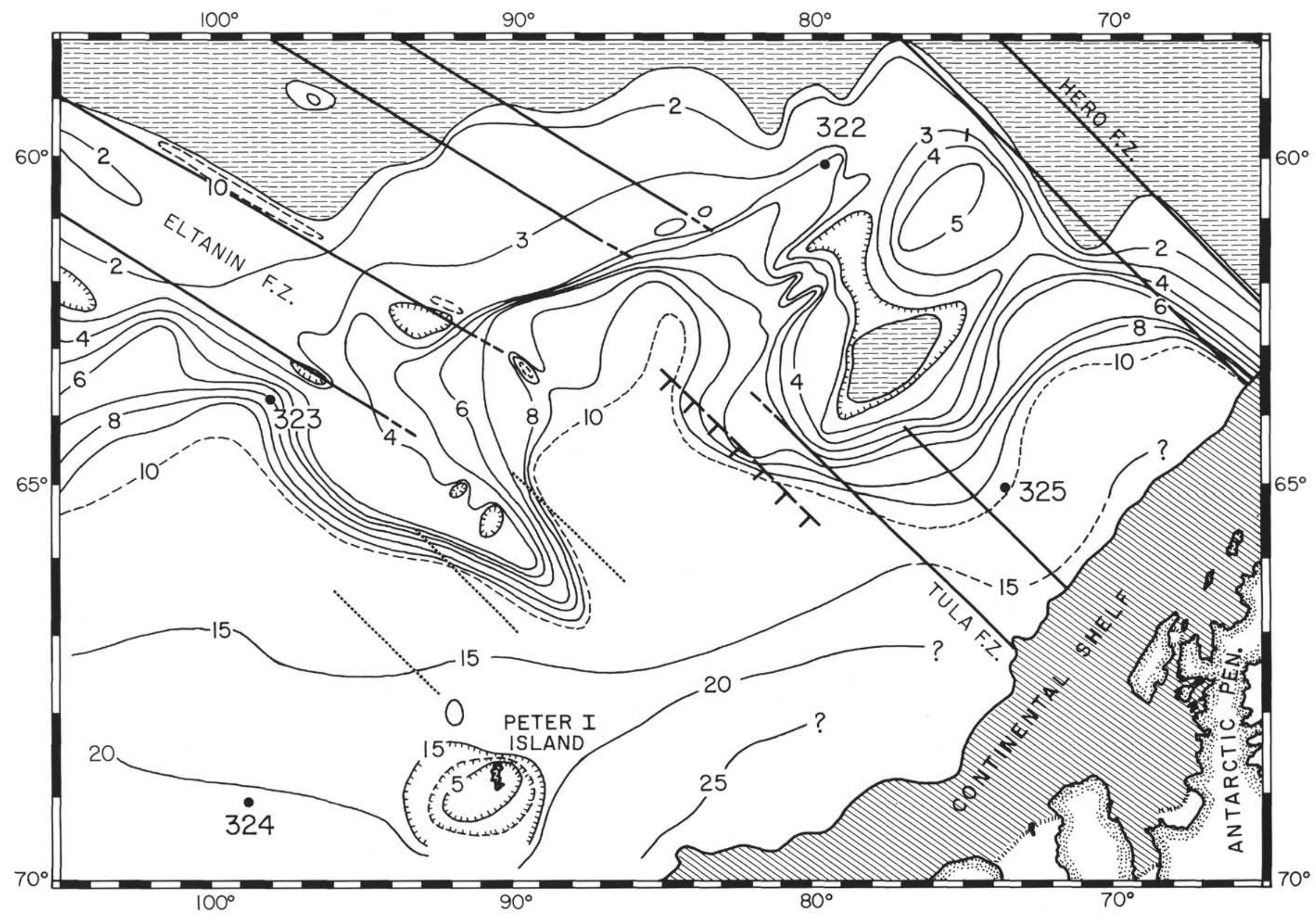

Figure 7. Generalized distribution of sediment in the Bellingshausen Basin, modified from Houtz et al. (1973) with recent data from Conrad 15 and Challenger 35. Sediment thickness is in tenths of seconds reflection time (two-way travel) and equals thickness in hundreds of meters at a nominal velocity of $2.0 \mathrm{~km} / \mathrm{sec}$. Horizontally shaded areas have less than one-tenth second of sediment cover. Known fracture zones are shown by solid lines, inferred fracture by dotted lines, and a 400-700 meter west-facing scarp in basement by the T pattern. 

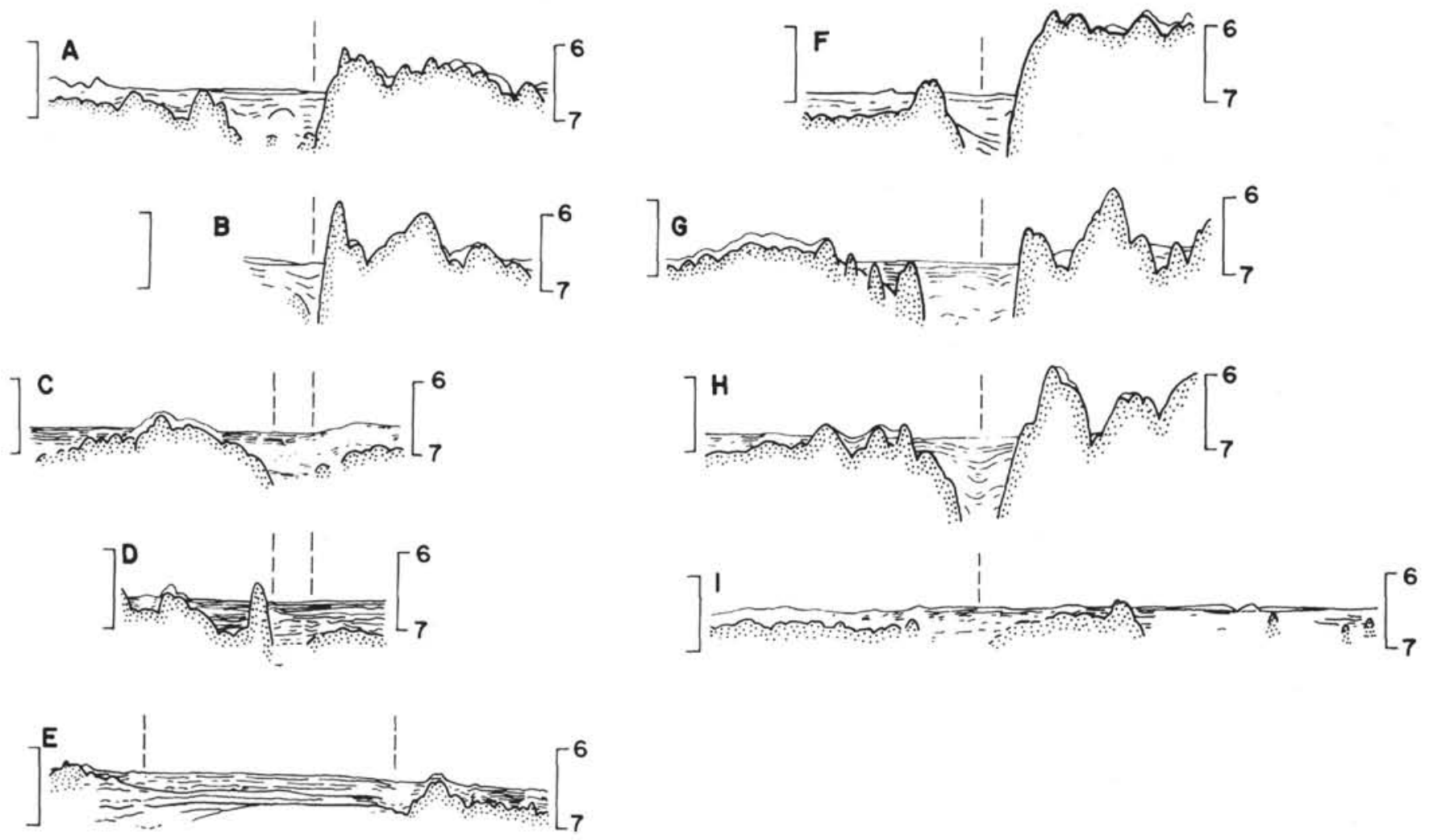

SOUTHERN

NORTHERN

Figure 8. Tracings of seismic profiles across the Eltanin Fracture Zone. Depths are in seconds reflection time. See Figure 11 for locations.

one-way vertical travel time. Because the Bellingshausen data are taken from a large region, they reflect the scatter that arises from wide areal sampling of an inhomogeneous sediment body. Even so, the velocity variability is similar to that observed in a composite plot of sonic-probe measurements made directly on the consolidated sediments recovered at Sites 322, 323, 324, and 325.

By way of comparison, a plot of velocity versus travel time for the adjacent southern Chile Trench shows relatively less scatter, but these data were obtained in a restricted area and are not subject to the variability introduced in wide areal sampling (Houtz et al., 1973).

The intercept velocities yielded by the regression equations in these plots are artifacts of the least-squares technique and have no significance. This results from our inability to obtain velocities near the sea floor with sonobuoys, and therefore this portion of the data is uncontrolled.

The difference between the slopes of the Bellingshausen Basin and Chile Trench plots is significant, but the cause is uncertain. The lesser increase of velocity with depth in the Bellingshausen Basin may be related to more rapid sediment emplacement in the basin adjacent to Antarctica. Compared with velocity plots obtained elsewhere in the world's oceans (Houtz, 1974b), the Chile Trench velocities increase unusually rapidly with depth and the Bellingshausen sediment velocities are excessively scattered.

Velocity and profiler data taken along two tracks above the slope and rise in the Bellingshausen Basin are used to construct cross-sections of true sediment thickness in Figure 10. Although evidence from magnetic lineations suggests that this margin is a former site of crustal subduction (see Herron and Tucholke, this volume), we no longer see any evidence of a trench in the deep seismic structure beneath the slope and rise.

A layer of velocity 4.2 to $4.6 \mathrm{~km} / \mathrm{sec}$ is frequently recorded in the Bellingshausen Basin sonobuoys at the depth of acoustic basement and above a $5.4-5.8 \mathrm{~km} / \mathrm{sec}$ layer. At sonobuoy 36-E42 (Figure 10), a weak second arrival indicates $4.0-4.5 \mathrm{~km} / \mathrm{sec}$ material above the 5.60 $\mathrm{km} / \mathrm{sec}$ layer, but the layer is too thin to be solved for a meaningful layer thickness. Elsewhere along the margin, including seven sonobuoys recorded farther seaward, the 4.2-4.6 $\mathrm{km} / \mathrm{sec}$ arrivals are rarely observed. However, the layer can be inferred in the records because the $5.6 \mathrm{~km} / \mathrm{sec}$ refractions arise from an interface about 300 meters below acoustic basement. This 4.2-4.6 $\mathrm{km} / \mathrm{sec}$ layer seems to be unique to the 

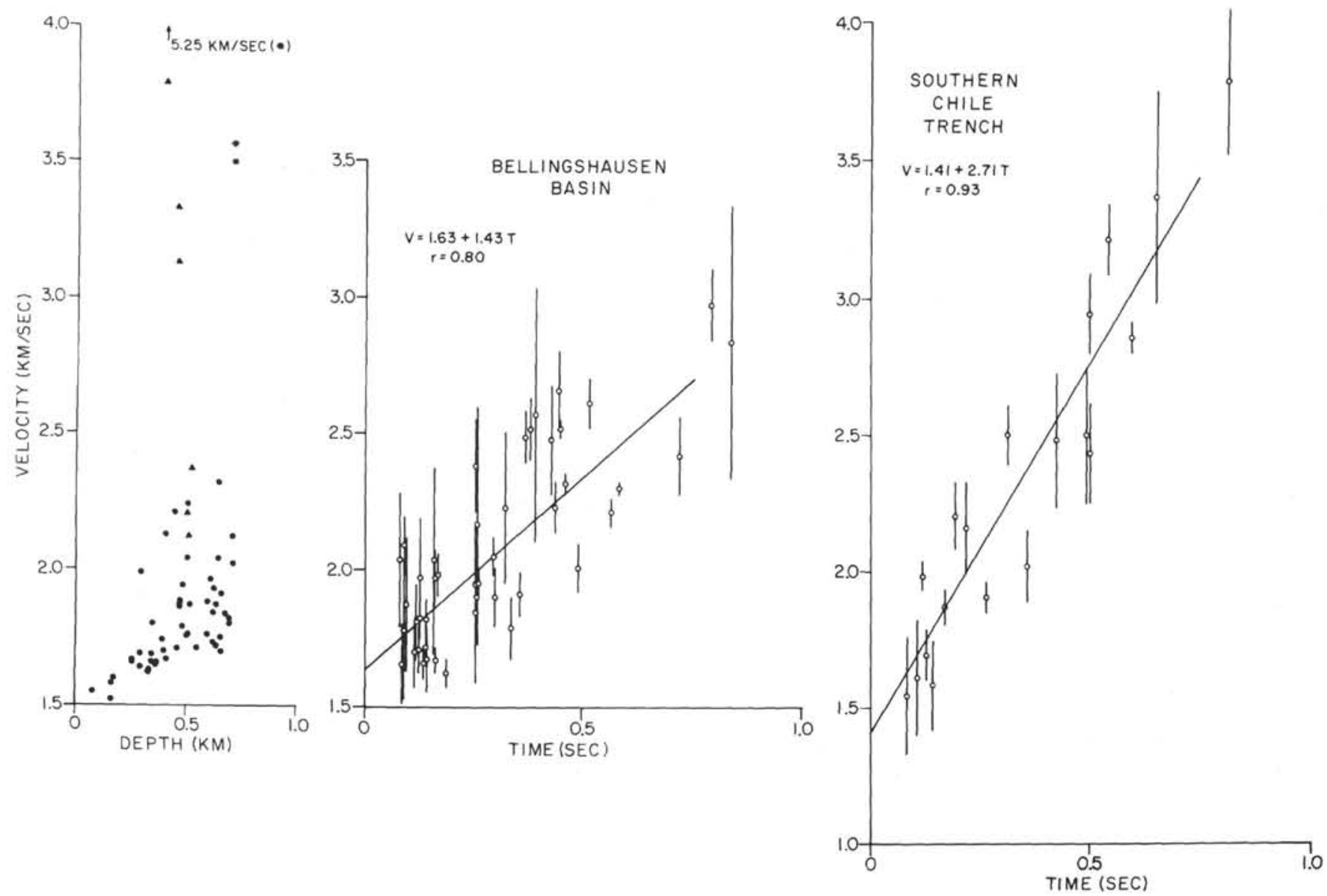

Figure 9. Plots of sound velocity averaged over individual layers versus one-way vertical travel time derived from sonobuoy solutions for the Bellingshausen Basin (center) and Chile Trench (right) from Houtz et al. (1973). The regression equations and correlation coefficients are shown. The plot at left is for directly measured sediment sumples (Hamilton frame velocimeter) at Sites 322 through 325 (triangles, chert; stars, calcite-cemented).

Bellingshausen Basin; it is not observed in the region of the nearby southern Chile Trench.

The thickness and position of this layer immediately below the acoustic-basement interface suggest that it may be Layer $2 \mathrm{~A}$. The term "Layer $2 \mathrm{~A}$ " was first coined by Talwani et al. (1971) in their study of the magnetics and sonobuoy data from the Reykjanes Ridge. The existence of the layer had already been widely documented in the Pacific (Houtz et al., 1970) where it was proposed in areas of relatively smooth acoustic basement and was though to consist of "cherts or volcanics." Our 4.2-4.6 $\mathrm{km} / \mathrm{sec}$ velocities are near the upper limit of those determined in these two studies, but they are still on the low end of normal Layer 2 velocities. Recent drilling on DSDP Leg 37 indicated that Layer $2 \mathrm{~A}$ in the North Atlantic consists of interbedded basalt and metasediments (Scientific Staff, 1974).

The 4.2-4.6 layer is thick enough to be resolved only in areas of smooth acoustic basement in the Bellingshausen Basin (Herron and Tucholke, this volume), and it is possible that lithified high-velocity sediment forms the upper part of the layer in these areas.

\section{ACOUSTIC SIGNATURE AND BASIN SEDIMENTATION PROCESS}

In the following discussion the entire sediment column as it is observed in seismic profiler records is characterized according to its acoustic signature. The Eltanin and Conrad profiler records studied were normally filtered between 40 and $150 \mathrm{~Hz}$; the Challenger records are higher frequency, usually with a low cut of $80 \mathrm{~Hz}$ and high cut ranging up to $640 \mathrm{~Hz}$. Our observations of acoustic signature are necessarily qualitative because the resolution of thin reflecting horizons is greatly improved at higher frequencies. In our discussion of acoustic signature, we use the terms "laminated" and "nonlaminated" to designate the presence or absence of reflecting horizons; "stratified" refers to lithologic changes in the sediment column.

The profiler records indicate that the acoustic signature of the sediment column varies laterally in the basin, thus defining acoustic provinces, but it is more or less invariant downward within the sediment column. The acoustic character map in Figure 4 is based upon this generalization. The major exception to the downward invariance of acoustic signature is that reflectors become very weak or disappear at depth in all the acoustic provinces. However, this is thought to result from increasing uniformity in sediment physical properties due to compaction and consolidation at depth (see Tucholke and Edgar, this volume), rather than from the effect of primary sedimentation processes on the acoustic impedance characteristics. Other localized examples in which the acoustic signature changes marked- 

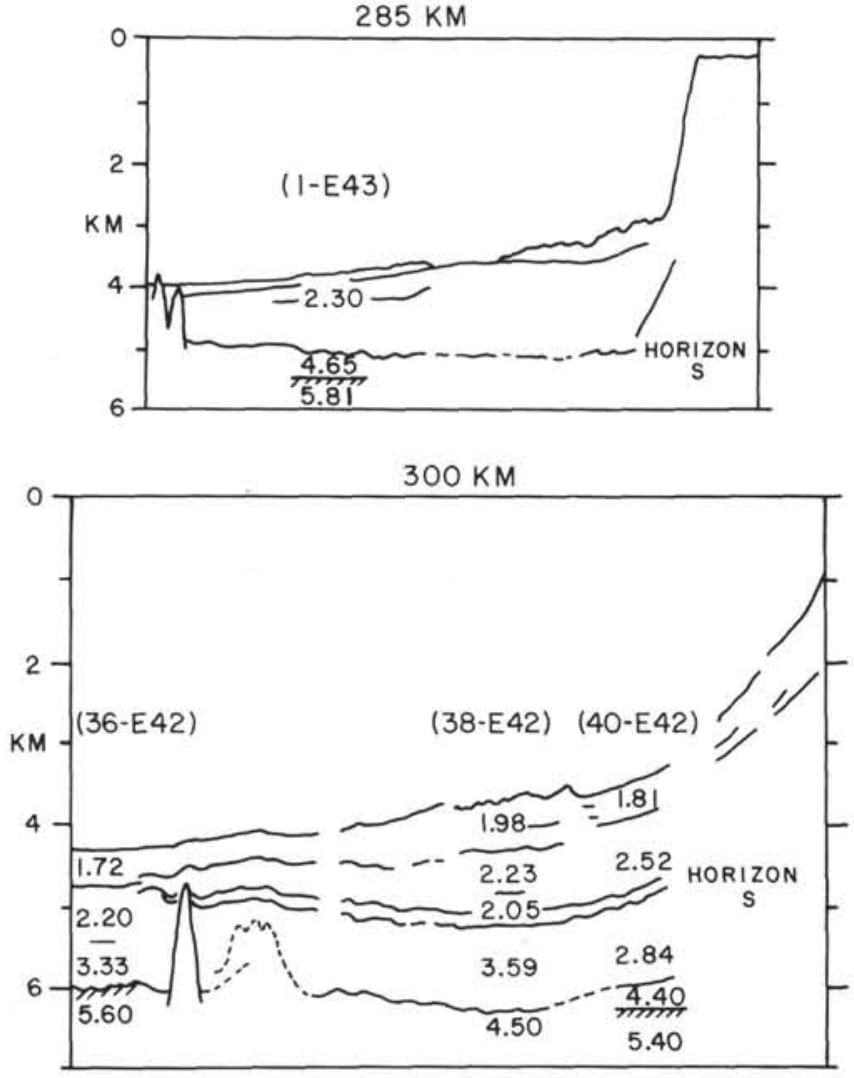

Figure 10. True-depth cross-sections of the Bellingshausen continental slope and rise, northeast (top) and southwest (bottom) of the Tula Fracture Zone. Sonobuoy velocity data $(\mathrm{km} / \mathrm{sec})$ are indicated. Figure modified from Houtz (1974a).

ly with depth are discussed separately below. Within this framework, the sea-floor morphology and changes in acoustic signature are used to interpret the sedimentary processes in the basin. The profiler records are presented in Figures 12-31; Figure 11 shows locations of the tracks.

The acoustic character of the continental rise is considered first. The rise can be subdivided into three acoustic provinces: (1) a zone of strongly reflective sediment with poor acoustic lamination on the upper continental rise; (2) less reflective sediments with fine acoustic laminae, confined mostly to the central continental rise; and (3) reflective sediments exhibiting moderate to good acoustic lamination on the lower continental rise. The boundaries between these provinces are in all cases gradational.

\section{Upper Continental Rise}

The highly reflective, poorly laminated sediments on the upper rise extend up to $100 \mathrm{~km}$ seaward from the base of the slope (province 6, Figure 4), but they form only a narrow belt northeast of the Tula Fracture Zone. The sea floor is fairly smooth and sloping along the southwest margin and becomes irregular and dissected in the northeast (Figures 12-14). We interpret this province as sediment deposited rapidly and chaotically from the continental slope by gravitational processes.
The dissected sea floor northeast of the Tula Fracture Zone is probably due to postdepositional modification by localized slumping and erosion by high-energy turbidity currents. The abrupt break in slope in the northeast area seems to be the locus of chaotic deposition. To the southwest, however, there is no sharp change in sea-floor gradient at the slope/rise transition, and the processes responsible for this acoustic regime appear to persist farther seaward.

\section{Central Continental Rise}

Finely laminated sediments are normally observed in profiler records under the central continental rise (Province 5, Figure 4; Figures 13, 14, 17-19). The fine acoustic laminae in this province can usually be traced for several tens to hundreds of kilometers. Three important features are superimposed on this acoustic province and are largely restricted to it: (a) submarine channels, (b) abyssal sediment waves, and (c) smaller-scale dunes.

Submarine channels appear to represent the primary paths of turbidity currents, and they are well developed and usually readily identifiable in the finely laminated sediments. In the vicinity of Site 325 they appear to form a dendritic pattern of distributive channels (see Schroeder, this volume), but in other areas profiler data are usually insufficient to definitely establish the nature of the channel system. The major channel at $86^{\circ} \mathrm{W}$ (Figures 2 and 4) apparently bifurcates and probably forms smaller dispersive channels on the lower continental rise.

In cross-section, the channels are almost universally characterized by migration of the channel axis ascending to the east through time (to the right, looking downchannel; Figures 20-22). Coriolis forces in the southern hemisphere cause turbid flows descending the channels to bear left; it is apparent that deposition on the left banks of the channels has forced eastward migration of their axes. Deposition on the side of the channel where flow is concentrated and the dispersive nature of the channels establish the central continental rise as a zone of rapid sediment accumulation from turbidity currents and their channel bank overflow. Higher velocity, erosional turbidity currents would have caused channel axis migration to the left (west).

The acoustic character of the channels is tremendously variable (Figures $4,20-22$ ). Buried patches of reflective sediment may indicate abandoned channels in several places. Other channels appear to be choked by chaotic debris or to have a veneer of pelagic sediment (observed in PDR records) which indicates that they are inactive. Since the best resolution in the profiler records in only about 40 meters, it is possible that many of the channels tagged as active in Figure 4 are in fact inactive and covered by a layer of pelagic or hemipelagic sediment. However, preliminary core descriptions from Eltanin cruise 42 (Frakes, 1971) indicate that sharpbased sand layers are common in the upper few meters of the sediment column in the western Bellingshausen Basin. Three piston cores taken on Conrad cruise 15 in the eastern basin contain similar layers; one of the cores was recovered just west of Site 322, one upslope from Site 325 in a channel, and one downslope from Site 325 


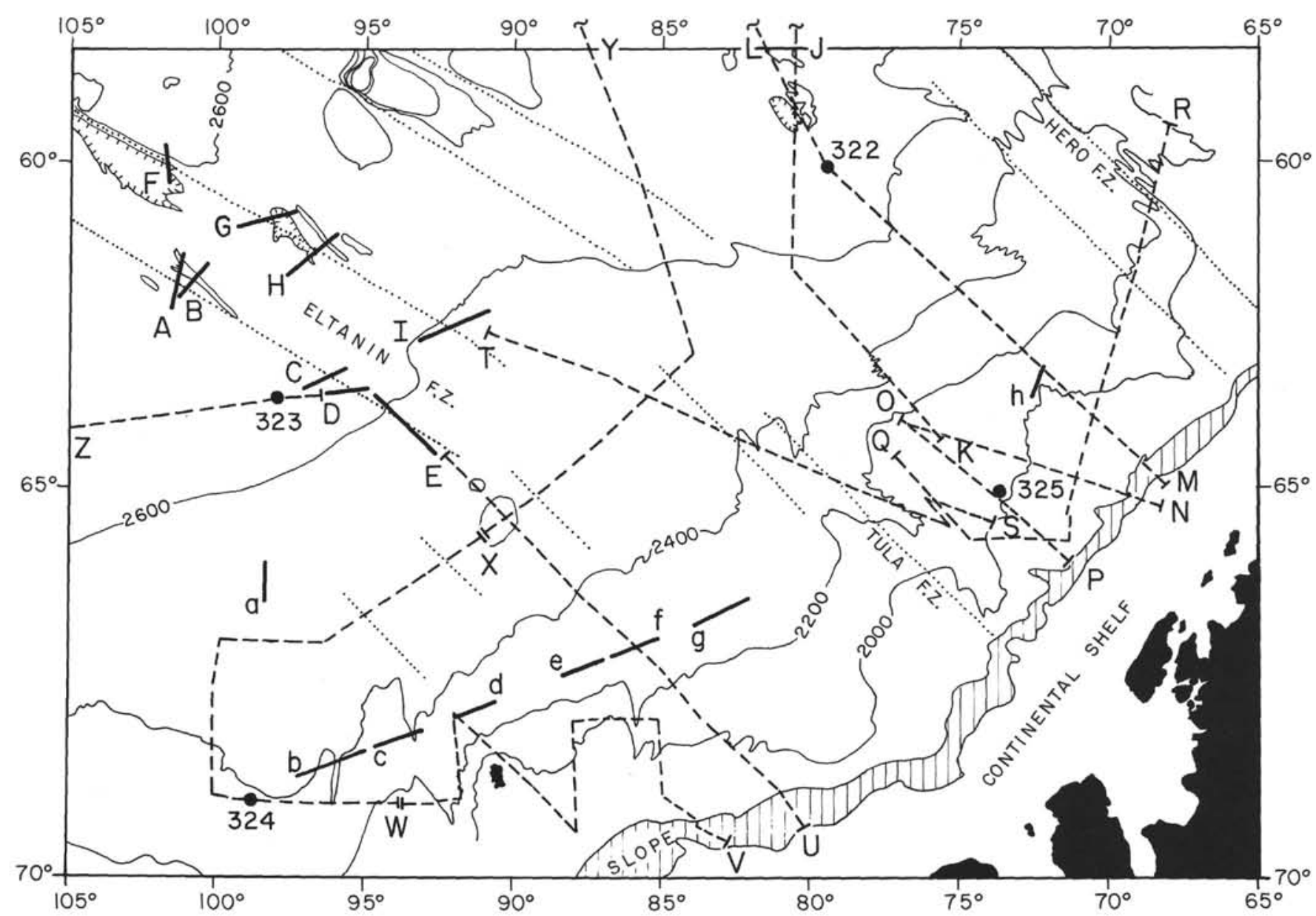

Figure 11. Location chart for seismic profiler records discussed in this chapter. Simplified bathymetry at 200 fm interval for 2000-3000 fm. Fracture zones are dotted.

on a small channel levee. Recent turbidity current activity $(<10,000 \mathrm{yr}$ B.P. $)$ therefore is inferred in many of the channels throughout the basin.

It is noteworthy that many of the channels include in their buried seismic signature a thin series of strong reflectors generally localized in the vicinity of the channel and about $0.2 \mathrm{sec}$ subbottom (Figures 20-22). The character of these reflective intervals indicates that they could be caused by massive sheet flows of sediment, and their similarity suggests that they result from a common period of increased turbidity-current activity. Although reflectors are less well defined in interchannel areas, careful study of the Challenger profiler record between Sites 324 and 325 suggests that the reflective intervals either lie above or correlate with a common reflective horizon, here called Horizon $\mathrm{R}$ (Figure 23). Traced westward to Site 324, Horizon R appears to correlate with the top of the highly reflective sequence underlying the nonlaminated sediments drilled and dated as Pliocene. If Horizon $\mathrm{R}$ is a chronostratigraphic horizon and is caused by increased deposition of coarse clastics, it may relate to the early Pliocene glacial pulse (about 4.5 m.y.) suggested by Hayes and Frakes (1975) or to later glaciation of West Antarctica $(<3.85$ m.y.) suggested by Ciesielski and Weaver (1974). Hayes and Frakes suggest that the earlier glaciation was extensive and included grounded shelf ice in the Ross Sea. Such intense glaciation could account for the apparent glacial scour on the West Antarctic continental shelf (Figures 5 and 6), and it would supply abundant ice-rafted debris to interchannel areas as well as sediment for generation of turbidity currents.

The submarine channels usually exhibit levees on their western side. The levees vary from well-developed, nonlaminated and finely laminated wedges to barely detectable accumulations with acoustic character similar to the interchannel areas (Figures 20-22). Although it is not entirely clear from the seismic profiler records, the morphology and reflective nature of the sea floor just east of Site 324 suggest that the area may be a broad shallow channel for turbidite dispersal. If so, the nonlaminated wedge at Site 324 could be the corresponding channel levee.

All the abyssal sediment waves observed on the continental rise are restricted to channel levees (Figures 20 and 24). They are best developed beside the channels at $86^{\circ} \mathrm{W}$ and $71^{\circ} \mathrm{W}$ and have migrated westward away from the channels. The sediment waves at $71^{\circ} \mathrm{W}$ have wavelengths of 4 to $9 \mathrm{~km}$ and are typical of those deposited from bottom currents in many areas of the world oceans (Fox and Heezen, 1968; M. Ewing et al., 1971; Jones et al., 1970; Tucholke and Ewing, 1974). 


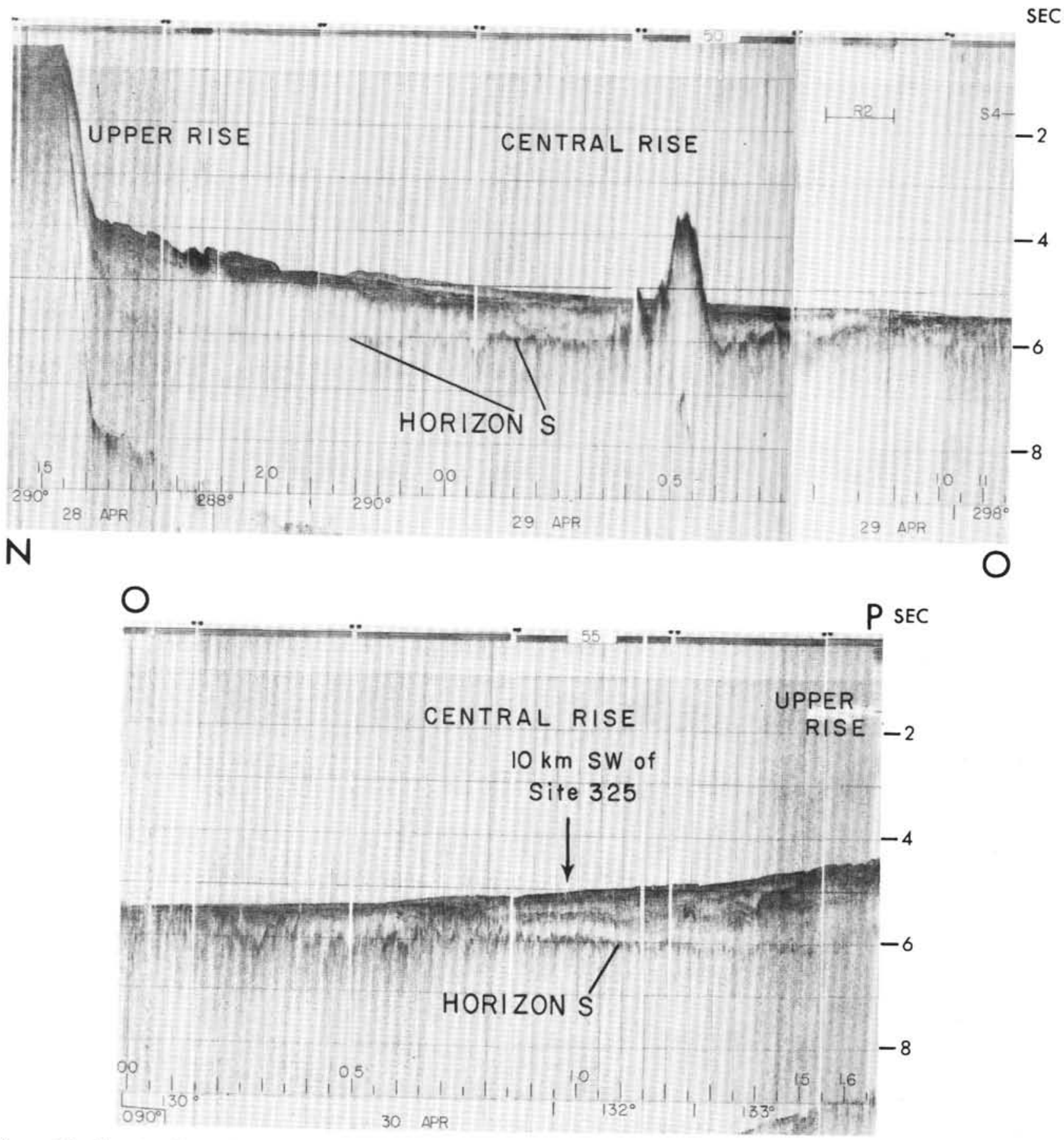

Figure 12. Eltanin 43 profiles near Site 325. Locations in Figure 11.

Challenger and Eltanin profiles intersect in this area, but the $71^{\circ} \mathrm{W}$ channel is poorly defined in the Challenger record, which crosses the channel slightly downslope from Eltanin. Rapid deposition of sediment is suggested by the sharp deterioration of the channel, and it may have contributed to development of the massive sediment waves. Abyssal sediment waves beside other channels (notably at $86^{\circ} \mathrm{W}$ ) have longer wavelengths ( 8 $20 \mathrm{~km}$ ) and morphology dissimilar to the waves at $71^{\circ} \mathrm{W}$. Their development appears to be closely linked to evolution of the channels, with little control by bottom currents.

Smaller sediment dunes (wavelength about $1 \mathrm{~km}$ ) also occur in the finely laminated sediments of the central continental rise (Figure 23). Although these dunes in places are superimposed on channel levees and sediment waves, they also occur in interchannel areas and are apparently unrelated to the channels. Where present, they have migrated upslope and eastward, and their best development is on the locally steep continental rise 

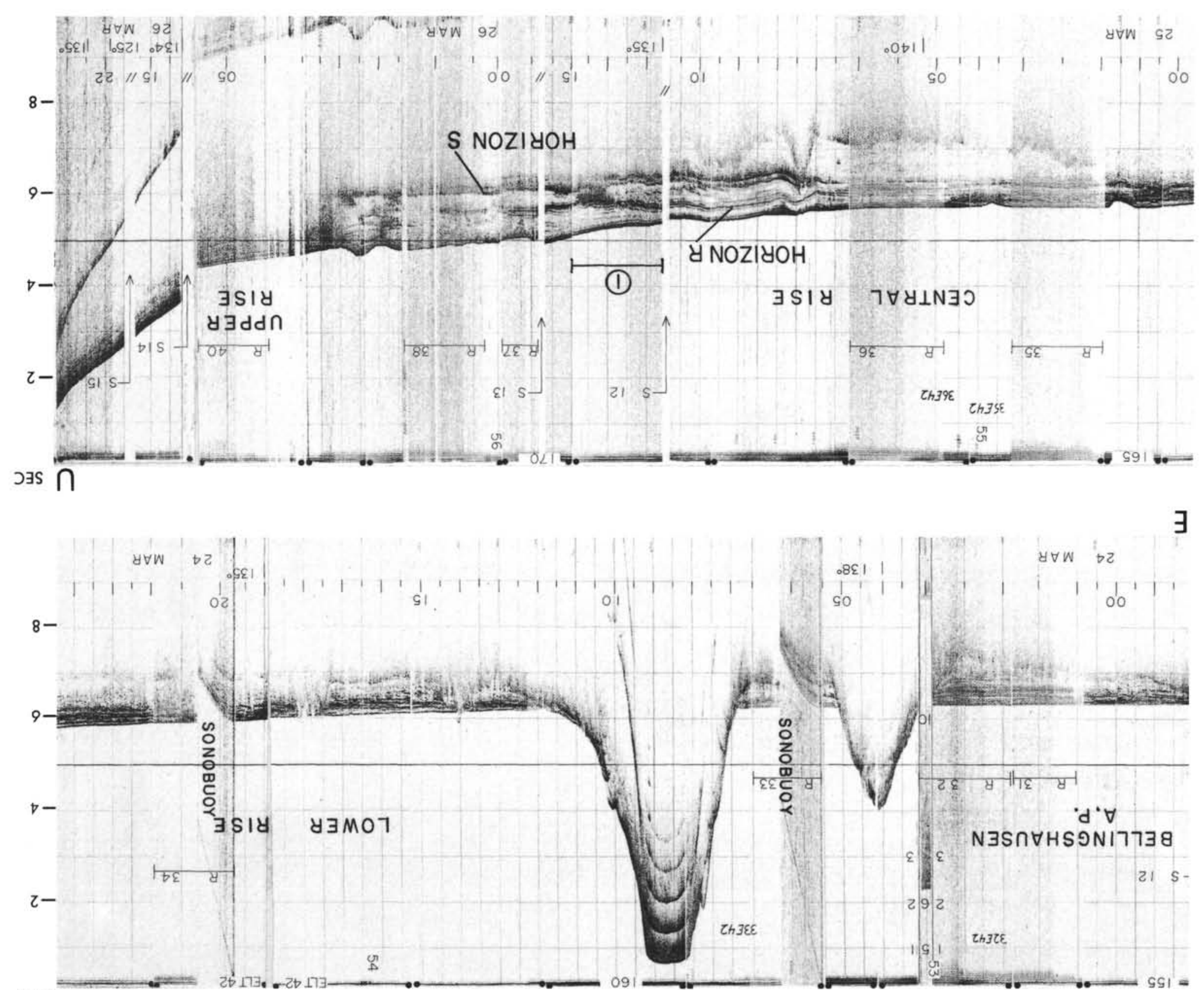

${ }^{\exists S}$ Figure 13. Eltanin 42 profile southwest of Tula Fracture Zone. Location in Figure 11. Circled number "1" locates Figure 25. 


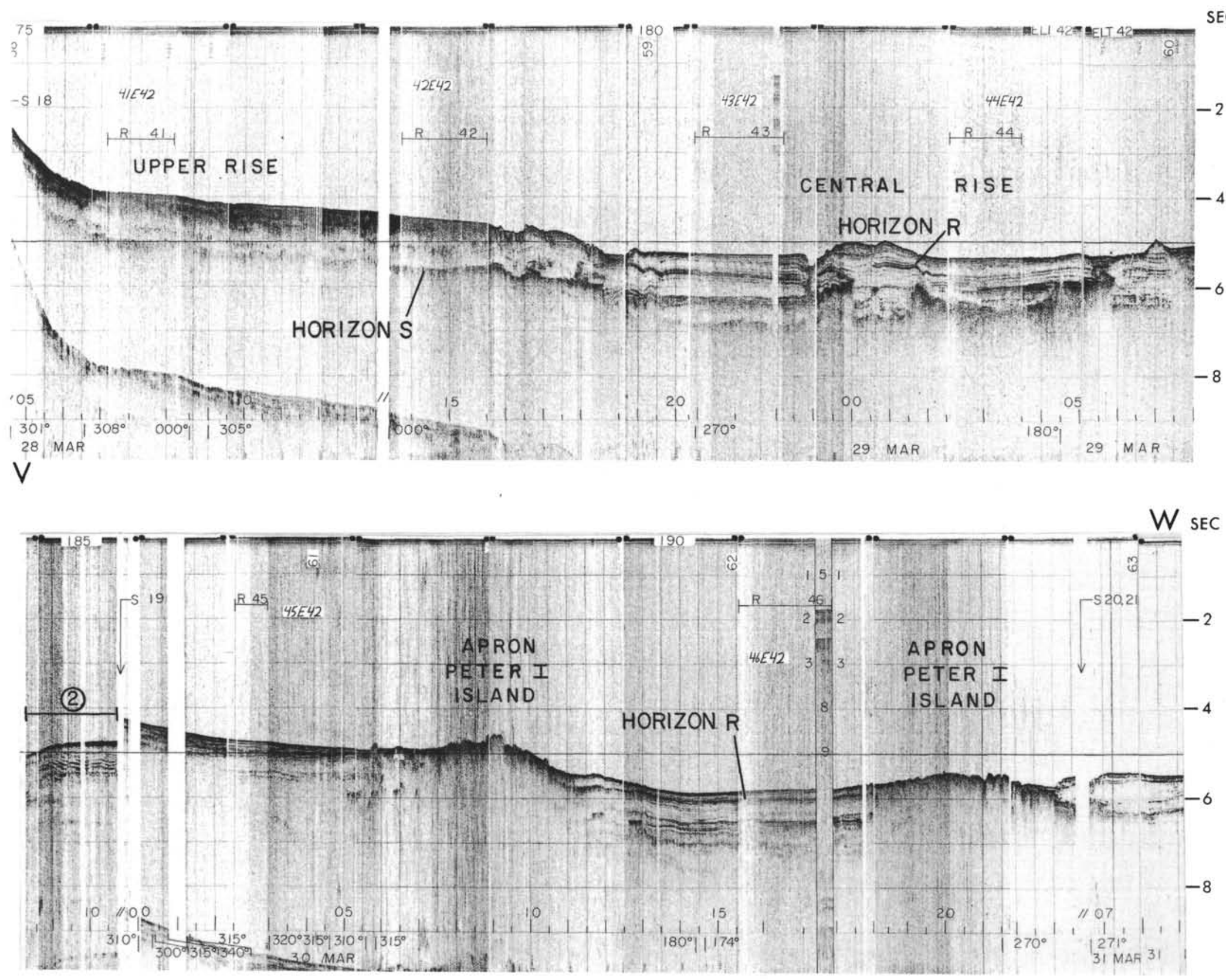

Figure 14. Eltanin 42 profile east of Site 324. Location in Figure 11. Circled number "2"locates Figure 25. 


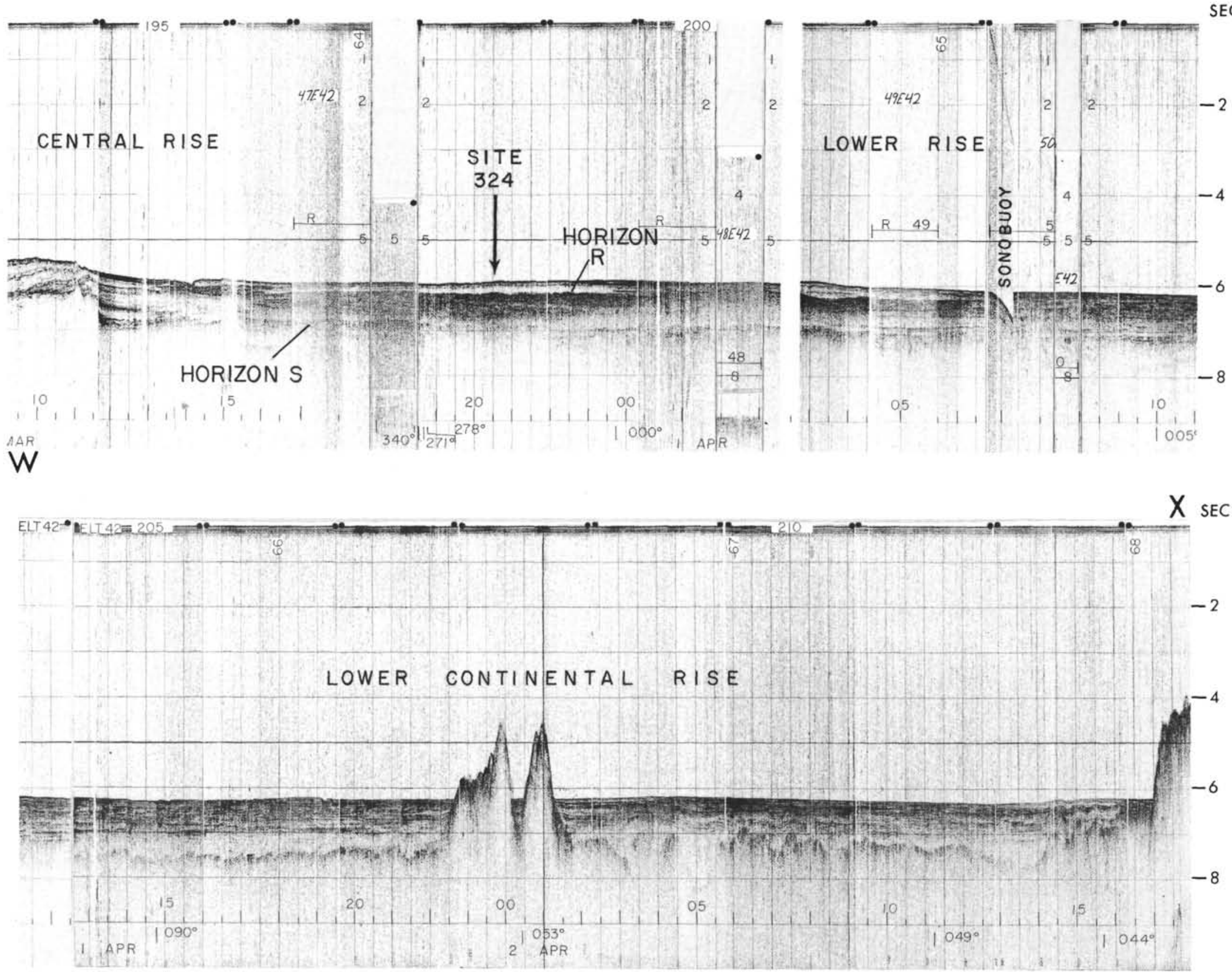

Figure 15. Eltanin 42 profile across Site 324 and lower continental rise north of site. Location in Figure 11. 


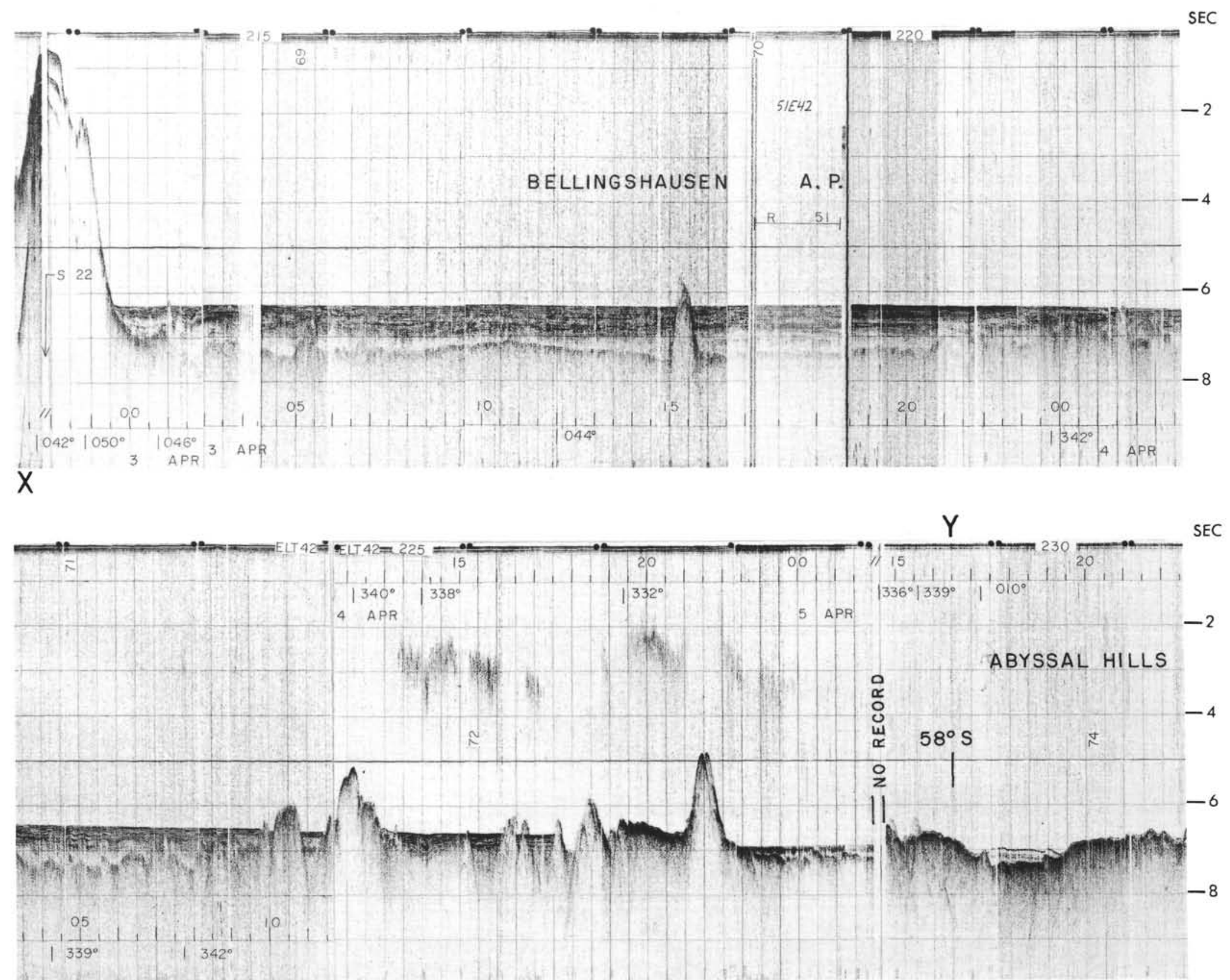

Figure 16. Eltanin 42 profile across Bellingshausen Abyssal Plain and abyssal hills to north. Location in Figure 11. 

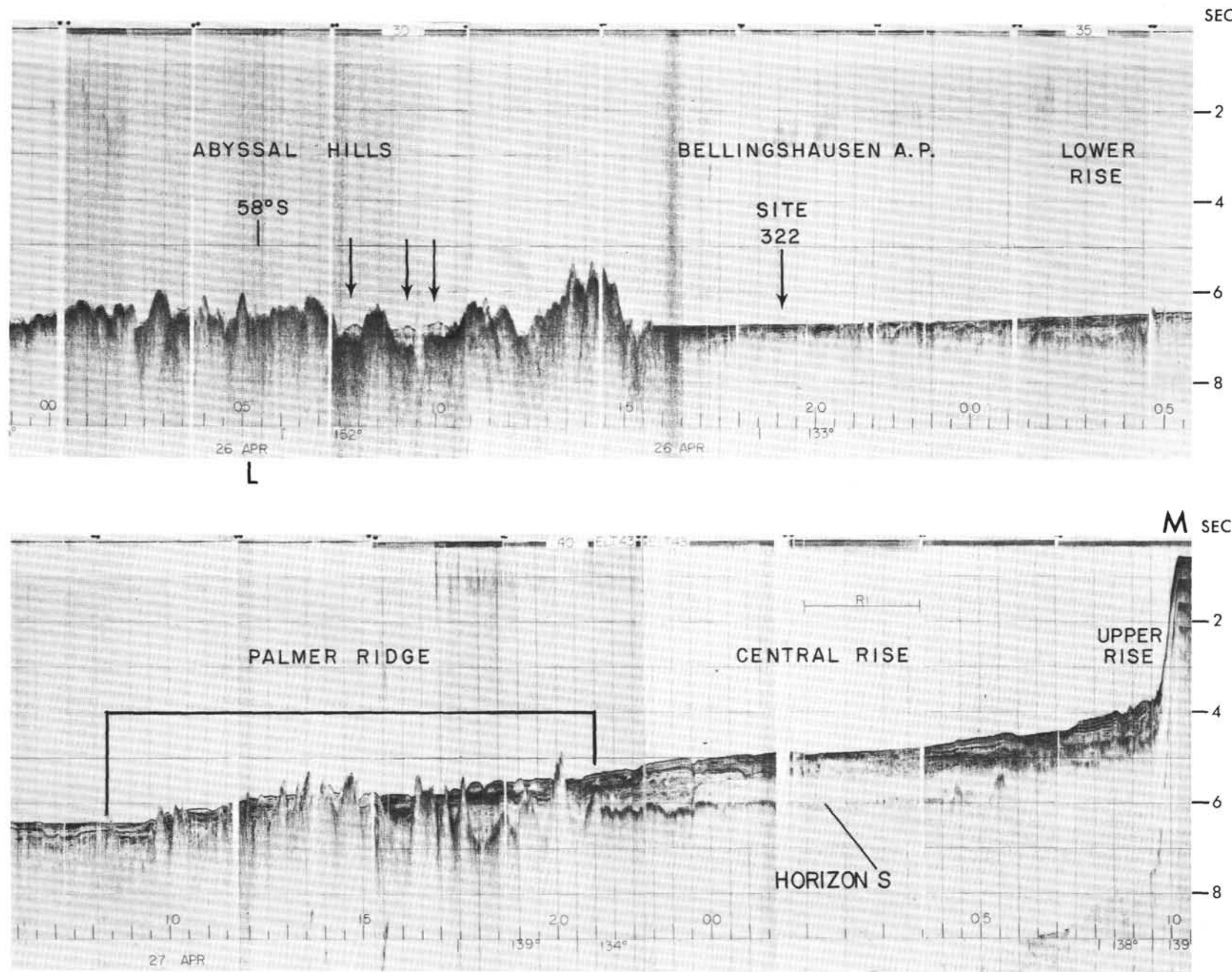

Figure 17. Eltanin 43 profile across Site 322 and continental margin to southeast. Arrows show current-deposited hummocks of sediment. Bracketed area indicates position of Figure 29. Location in Figure 11. 

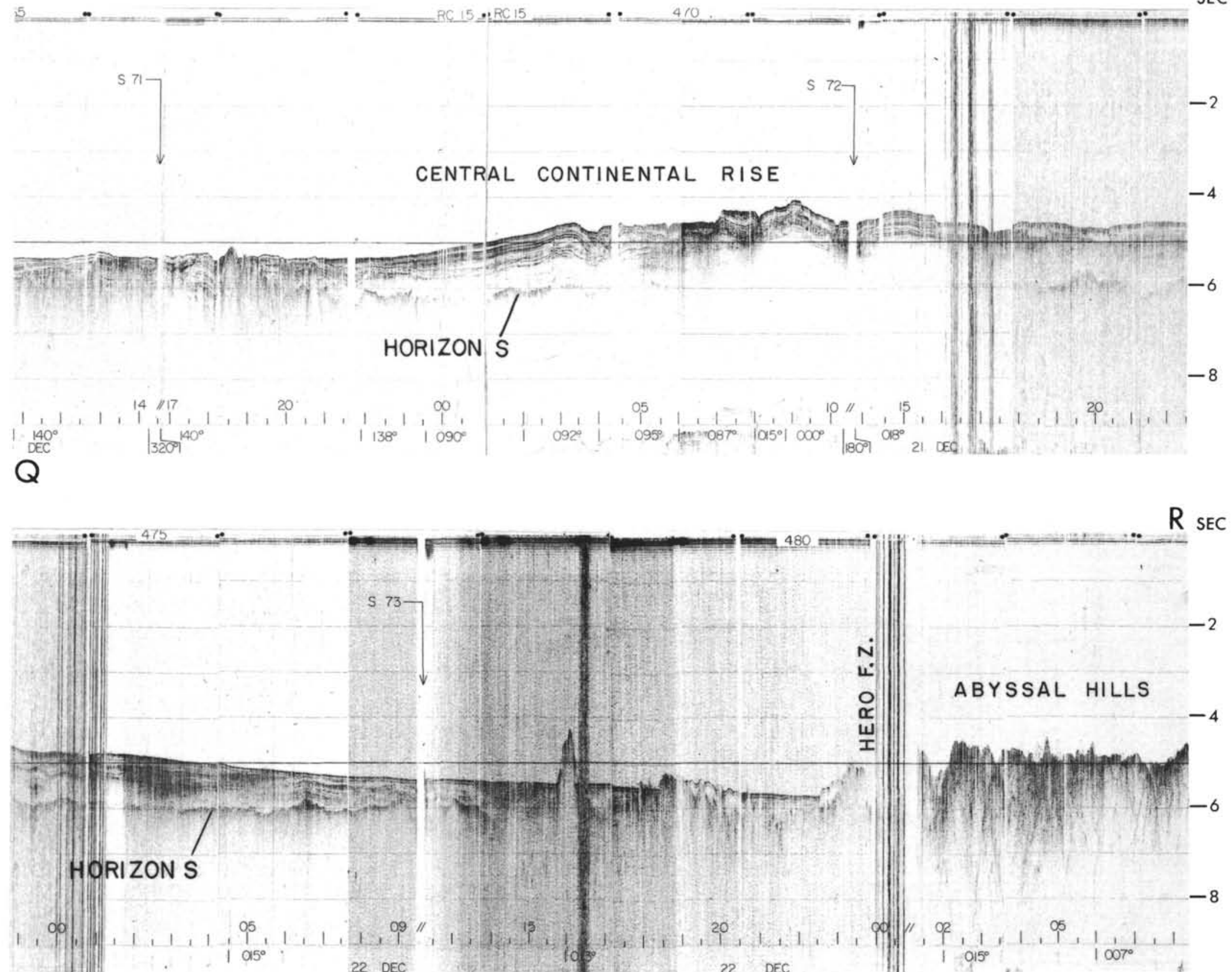

Figure 18. Conrad 15 profile across central continental rise near Site 325 and abyssal hills to northeast. Location in Figure 11. 


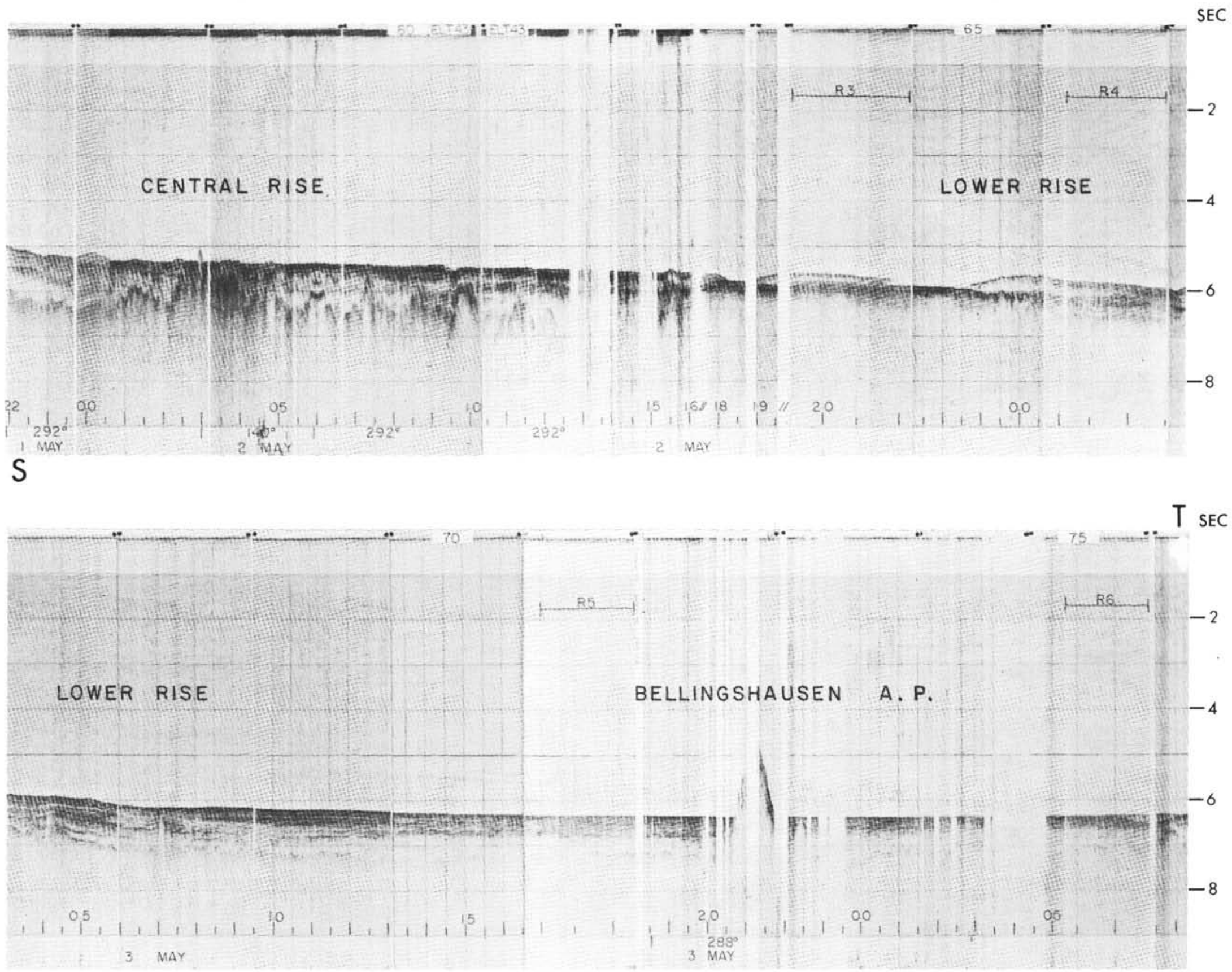

Figure 19. Eltanin 43 profile extending from near Site 325 northwest toward Eltanin Fracture Zone. Location in Figure 11. 

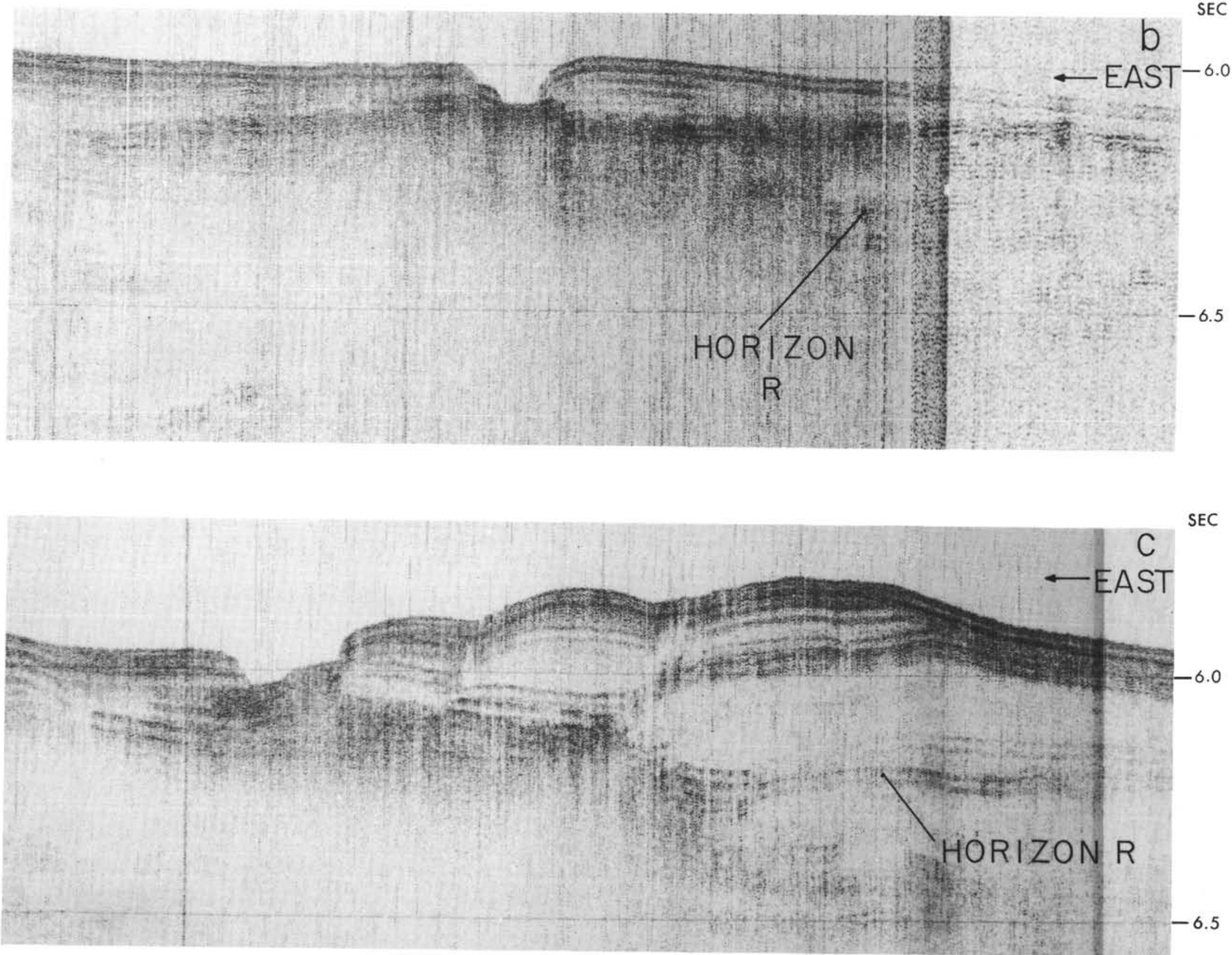

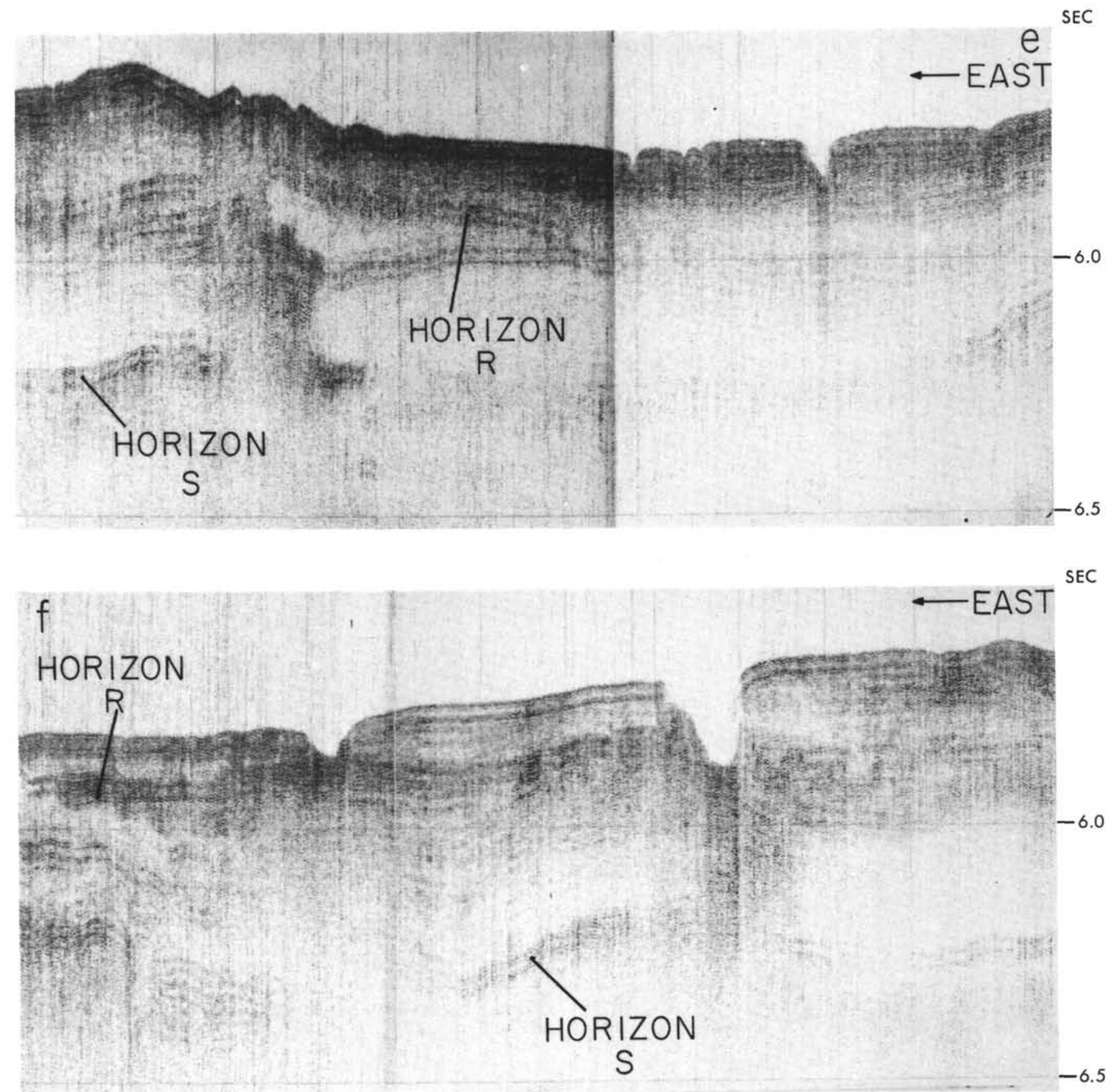

Figure 21. Challenger 35 profiles across channels in central continental rise between Sites 324 and 325 . Note buried channel at upper left. Locations in Figure 11.

north of Peter I Island. Eltanin 42 and Challenger tracks intersect in this region, showing that the dunes have migrated in the direction $\mathrm{N} 70^{\circ} \mathrm{E}$, about $40^{\circ}$ to the regional topography; the plane through their buried peaks dips about $22^{\circ}$ in the direction $\mathrm{S} 70^{\circ} \mathrm{W}$.

Similar sediment dunes have been observed in the world oceans in areas of moderate to strong bottom currents. Where surveyed in detail, the dunes appear to migrate upcurrent and upslope at an angle of $35^{\circ}$ to $45^{\circ}$ with the regional contours (Hollister et al., 1974). Thus, the dunes on the Bellingshausen continental rise are indicative of a westward-flowing bottom current, and their best development is on the locally steeper sea floor where the flow should be intensified.

The bottom current that may be responsible for the dune development has been discussed by Hollister and Heezen (1967); they used the distribution of potential temperature in the bottom water to identify the current as water originating in the Weddell Sea and flowing west along the continental rise of West Antarctica. Subsequent, short-term ( $<5 \mathrm{~min})$ current measurements reported by Jacobs et al. (1972) on the Bellingshausen slope and upper rise suggest a westward bottom flow at speeds up to $12 \mathrm{~cm} / \mathrm{sec}$ (most $<7 \mathrm{~cm} / \mathrm{sec}$ ). However, 

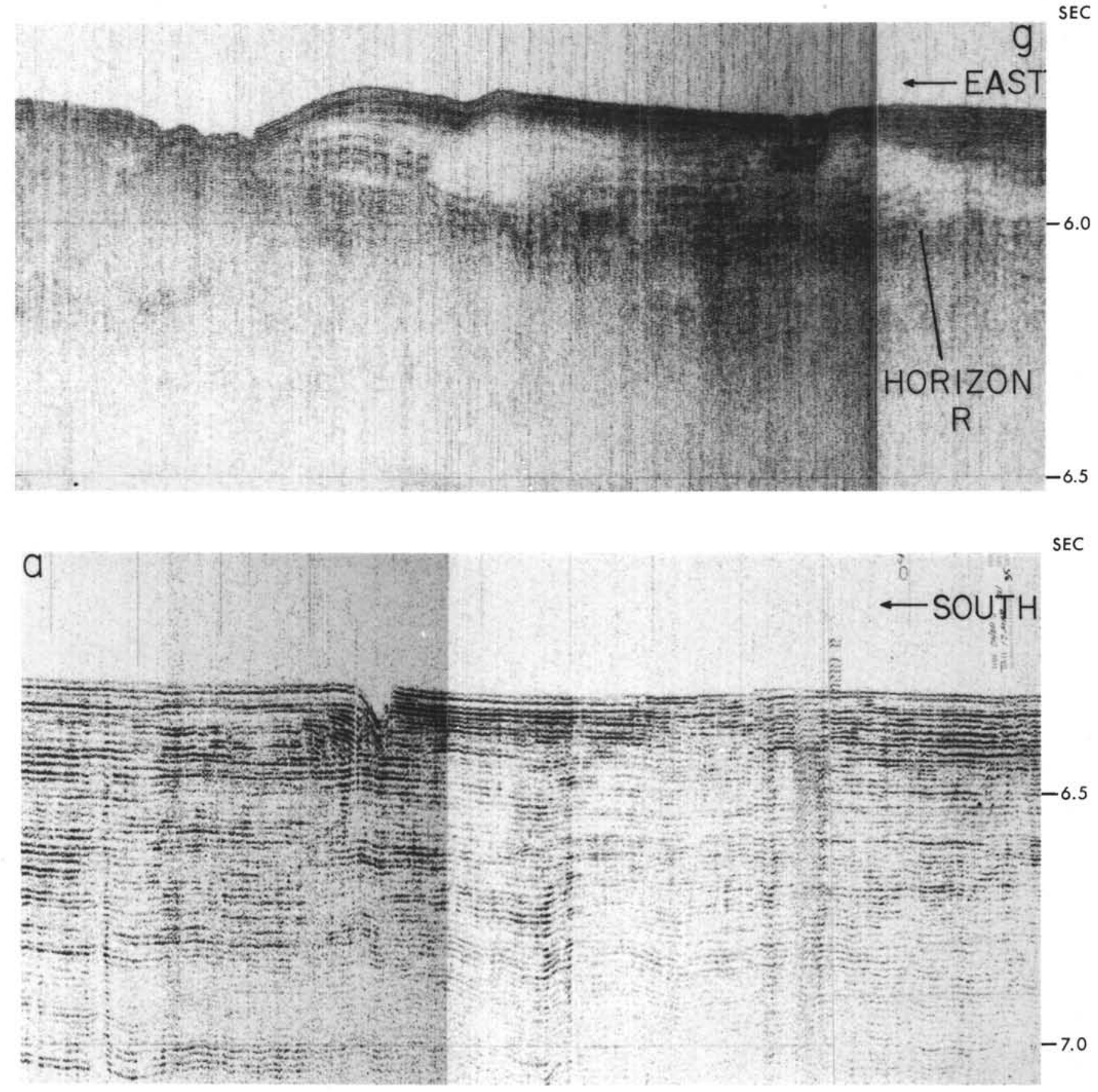

Figure 22. Challenger 35 profile across choked channel on central continental rise (upper) and small channel in laminated sediments of lower rise (lower). Locations in Figure 11.

their bottom photographs show little evidence of currents and suggest that currents seldom exceed the erosional threshold. Further evidence for bottom currents is indicated by sea-floor hyperbolae observed in $3.5-\mathrm{kHz}$ records where the flow is locally accelerated around the seamounts north of Site 325 (see Roberts et al., 1974; Schroeder, this volume). Hyperbolated sea floors in many areas of the world's oceans have been interpreted to result from bottom current activity (Heezen et al., 1966; Hollister and Heezen, 1972).

A moderately well developed nepheloid layer observed on the continental rise during Eltanin cruises 42 and 43 (Jacobs et al., 1972) supports the concept of recent current transportation of particulate matter. Based on the in situ nephelometer calibration of Biscaye and Eittreim (1974), actual suspended matter concentrations over the Bellingshausen continental rise probably approach $30 \mu \mathrm{g} /$ liter.

Although this diverse evidence supports the presence of a westward-flowing contour current along the rise, Reid and Nowlin (1971) found little evidence for transport of Weddell Sea water through the southern Drake Passage to the Bellingshausen continental rise. It may be that the contour current presently is supplied 


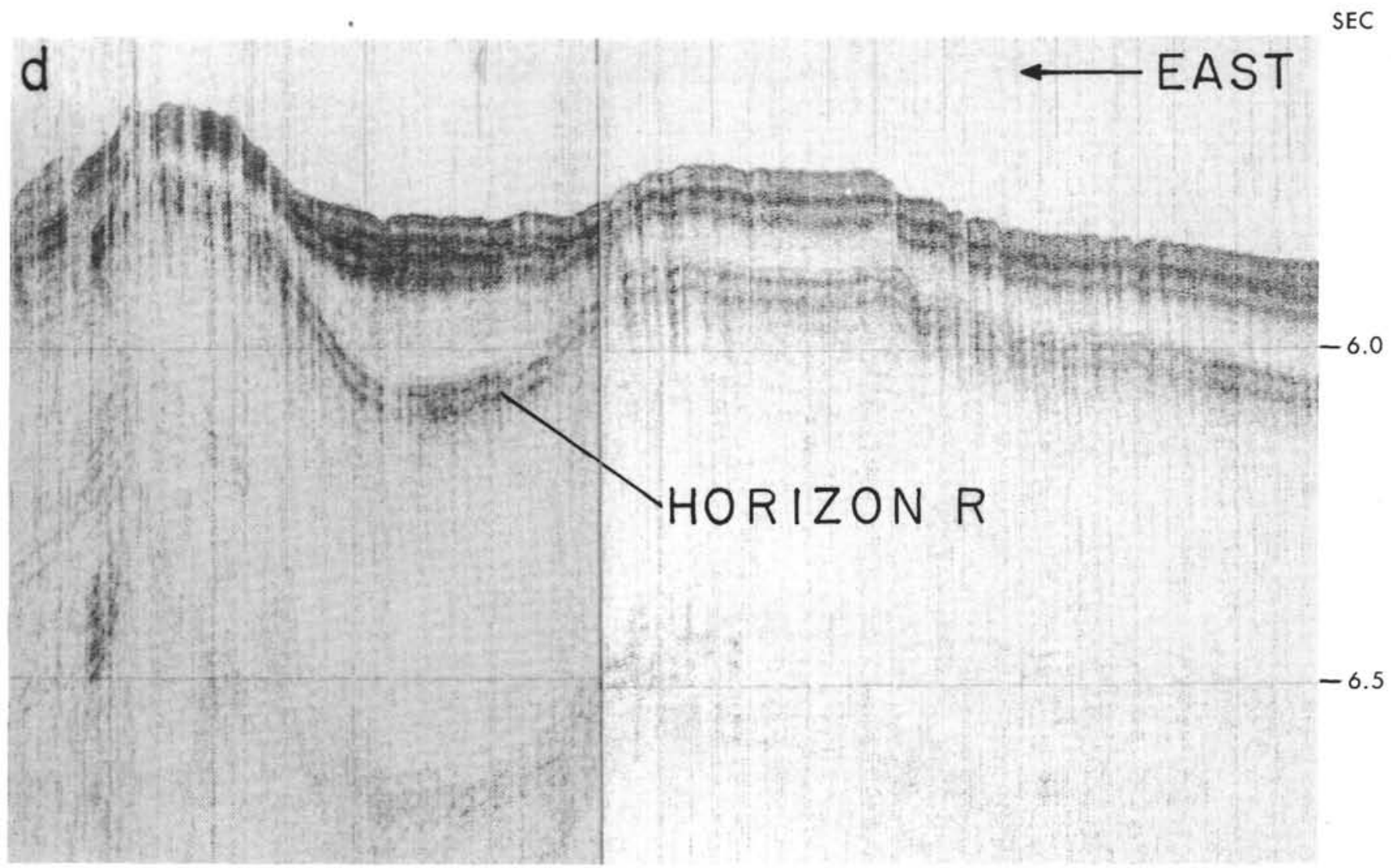

Figure 23. Challenger 35 profile north of Peter I Island showing small dunes and Horizon R. Location in Figure 11.

only intermittently with Weddell Sea water, or that modern conditions are atypical, whereas better developed currents affected the sediment distribution on the rise in the recent geologic past.

The sediment dunes attributed to this current are identifiable to about $0.6 \mathrm{sec}$ subbottom in the profiler records north of Peter I Island. If the contour current which produced the dunes was in fact controlled by bottom water originating in the Weddell Sea, dating of the most deeply buried dunes could provide a minimum age for the time when the Scotia Arc was breached to deep circulation. Unfortunately, there are no reliable data to establish this age; the crust underlying the dunes has a probably age of early Paleocene (anomaly 25 ) or older, and drilling at Site 324 to the west only penetrated to within about $0.4 \mathrm{sec}$ of the appropriate reflector, recovering (?) lower Pliocene sediment. Interpolation of ages between the appropriate horizons in the dune area (assuming a constant sedimentation rate) suggests initial dune formation during the late Oligocene to early Miocene. The oldest known ocean crust in the Drake Passage has a similar age (20-22 m.y.; Barker, 1971).

It is difficult to estimate the effect of the cross-canyon bottom current on levee formation. Although the westward-migrating sediment waves on the levees have apparently formed under the influence of channel-bank overflow from turbidity currents, the contour (crosscanyon) current has locally superimposed smaller dunes on the levees and has probably caused increased westward dispersal of the overflow. Based on the available evidence for contour currents and on the fine acoustic lamination in profiler records, the central continental rise is interpreted as a zone dominated by sediment deposition from a current-maintained nepheloid layer and from fine-fraction channel-bank overflow of turbidity currents.

Aside from the instance of Horizon R, we cannot realistically evaluate the effect of ice-rafting on the central rise. Compared to the textural/acoustic changes attributable to turbidity and contour currents, the effect of ice-rafted debris on the acoustic character of the sediment is probably minor in all but the most intense intervals of ice-rafting.

One further modification of the central continental rise is local postdepositional faulting. Unlike the chaotic disturbances on the upper rise, however, these faults are well defined, and associated slumping appears to be absent (Figure 25).

\section{Lower Continental Rise}

The transition to the lower continental rise, acoustic province 3 (Figure 4 ), generally occurs over a distance of tens of kilometers. The lower rise is strongly laminated and thus acoustically opaque, but the laminae are often discontinuous; only a few can be traced for more than a few tens of kilometers (Figures 13, 15, 19, 26). The process causing the strong, discontinuous acoustic lamination is interpreted to be rapid deposition of coarse terrigenous debris from turbidity currents. The regional gradient is low $(<1: 800)$, and rapid deposition from sheet-like flows can be expected. Restricted areas of dispersal for the coarsest fraction of turbidites would 


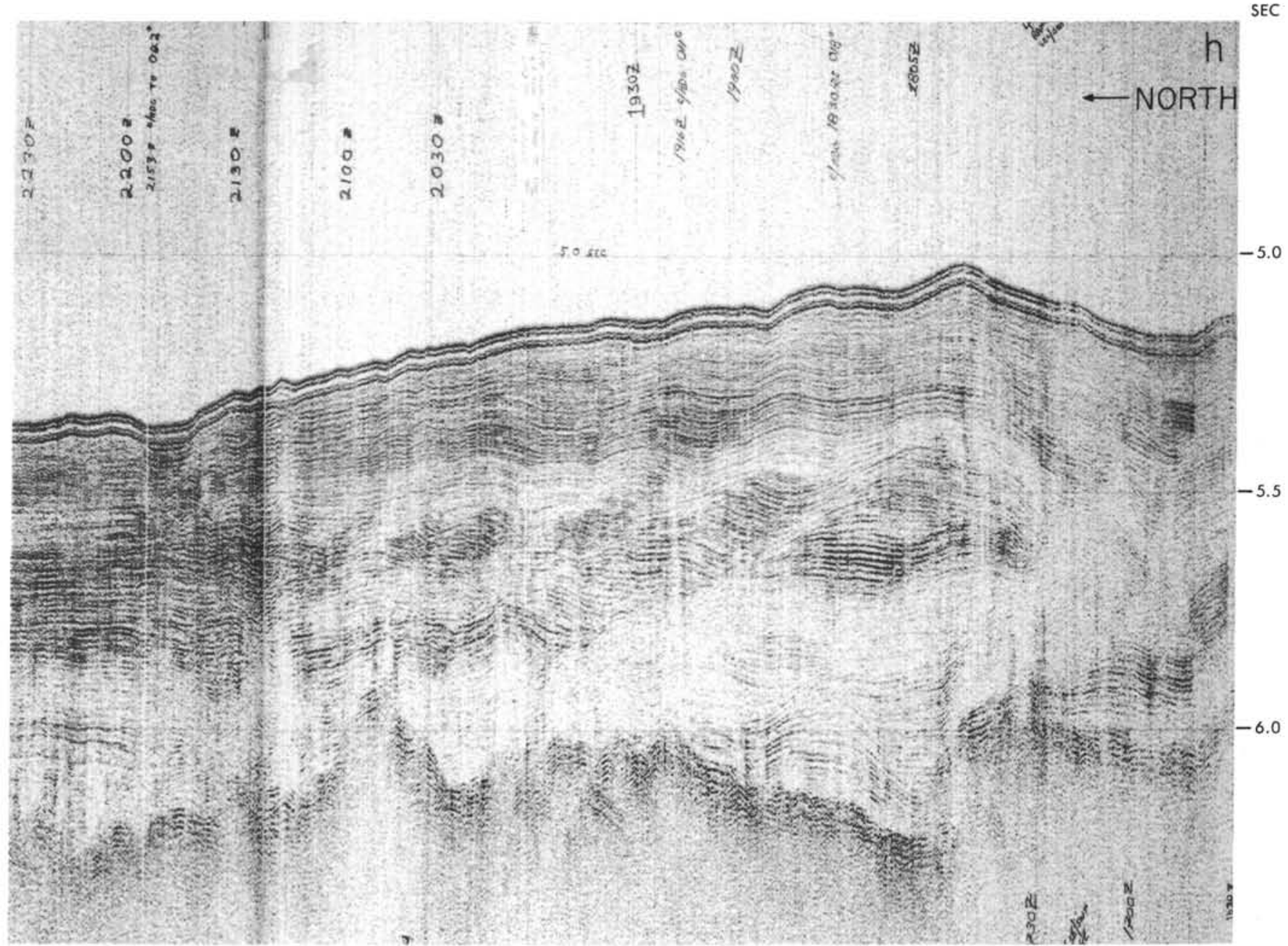

Figure 24. Challenger 35 profile on central rise northeast of Site 325 showing large abyssal sediment waves. Note poorly developed channel at left. Location on Figure 11.

result in a zone of discontinuous reflectors, and interbedded fine detritus could cause the strong impedance contrasts observed. Erosion and redeposition of sediment by bottom currents may also contribute to the discontinuity of reflectors; current-reworked sediment at Sites 322 and 323 is attributed to the effects of the Antarctic Circumpolar Current (see site reports, this volume).

Lenses of nonlaminated or weakly laminated sediment, interpreted as channel levees, locally onlap the laminated lower-rise sediments, as at Site 324 (Figure 15). No similar nonlaminated lenses are observed deeper within the acoustic record, and it appears that the lenses represent post-Miocene progradation of centralcontinental-rise deposits onto the lower rise.

The few seismic profiles which cross the lower continental rise also suggest it is nearly devoid of channels; channels which do appear are associated with nonlaminated levees or are poorly developed (Figure 22). No buried channels have been observed. Thus, the first distinct acoustic evidence of channeling appears where central-rise sediments prograde over the laminated lower-rise sediments.
If the above interpretations are correct, we should be able to look beneath the central continental rise and detect older, buried phases of the lower continental rise. We interpret Horizon S, buried beneath the central rise, as one of these phases (Figures 13,14); no channels are detected below this strongly reflective horizon. Because the seaward progradation of these sedimentary environments represents lateral movement with time, it is obvious that Horizon $\mathrm{S}$ is diachronous, or at best only locally synchronous if the progradation occurred in "jumps" rather than uniformly. Furthermore, Horizon $\mathrm{S}$ under the northeastern continental margin is unlikely to be synchronous with Horizon $\mathrm{S}$ under the southwestern margin, because the development of continental rise sedimentation has been controlled by the northeastward progression of crustal subduction along the continental margin.

\section{Bellingshausen Abyssal Plain}

The Bellingshausen Abyssal Plain, acoustic province 2 (Figure 4), has essentially the same acoustic signature and sedimentation processes as the lower continental rise. Discrete laminae appear to be better defined than 

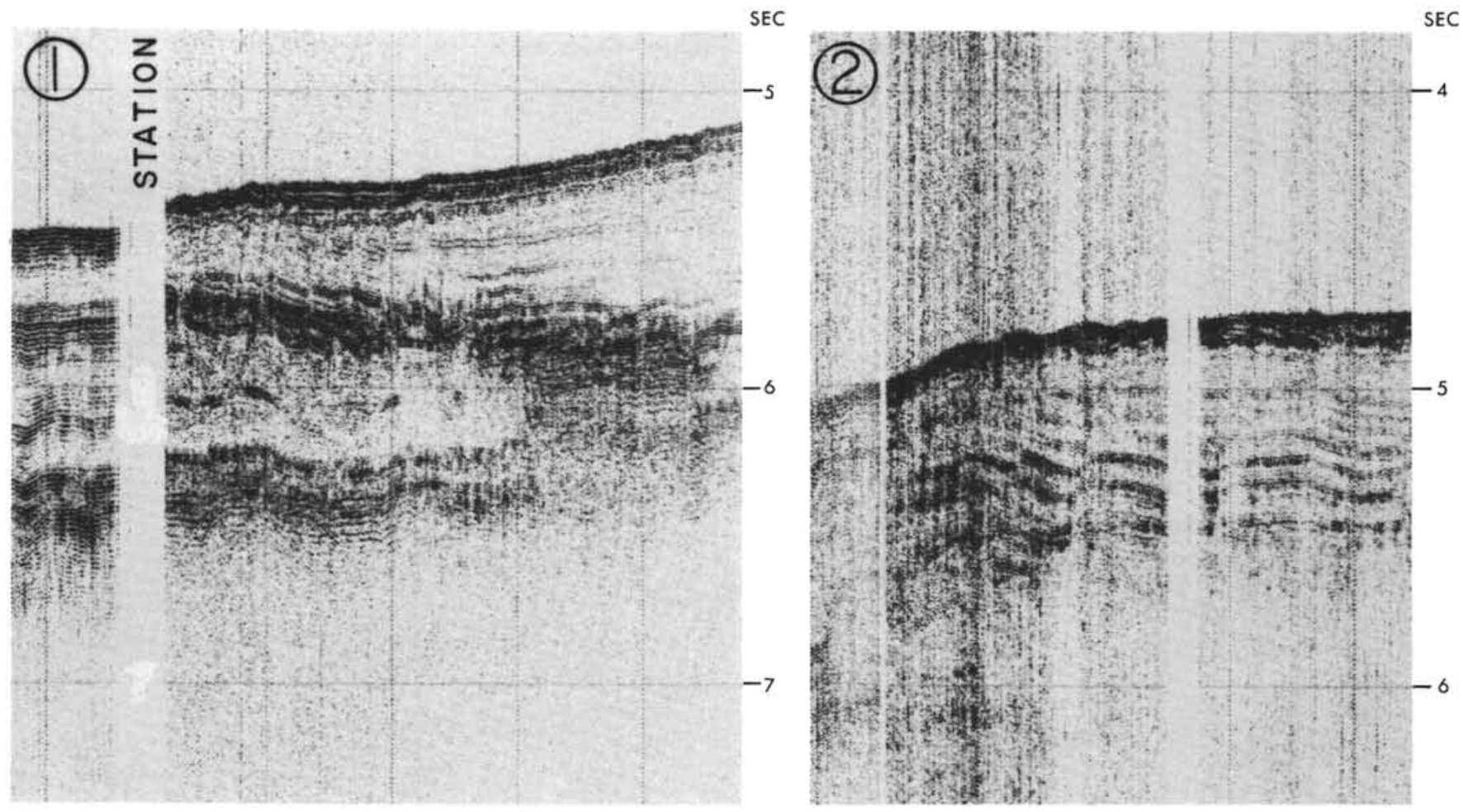

Figure 25. Enlargements of Eltanin 42 profiles on central rise showing postdepositional faulting. Locations in Figure 13 and 14.

on the lower rise, however, and they are especially distinct in the distal parts of the abyssal plain (Figure 16). The level attitude of the laminae is a clear indication of their turbidite origin although the deeper reflectors are commonly distorted by the effects of differential compaction above the underlying rough acoustic basement.

M. Ewing et al. (1968) noted that turbidites are ponded against the rough abyssal hill topography at the northern edge of the abyssal plain. In several places the turbidites are separated by a small ridge from an adjacent sediment-free deep (Figures 16, 17, 26; Houtz et al., 1973). The distribution of ponded sediments and sediment-free deeps suggests that a continuous barrier ridge lies along the fracture zone extending southeastward from $58^{\circ} \mathrm{S}, 94^{\circ} \mathrm{W}$ (Figure 4). The deeper pond to the northeast appears to have a southeasterly source; echo-sounding data show a gentle northwestward slope from the main abyssal plain toward this pond.

The fracture zones southwest of this area also have a ridge on their southern margin (Figure 8), but the ridge is deep and discontinuous so that turbidites have flooded the fracture zones. Sediments ponded in parts of these fractures remote from a sediment source are generally weakly laminated, probably reflecting the distal deposition of very fine grained turbidites. The ponds occur at several levels and reflect complex sediment dispersal paths in the rough topography. Survey data are as yet insufficient to trace this system in detail.

\section{Abyssal Hills}

Most of the topographic roughness in the abyssal hills, acoustic province 1 (Figure 4), reflects the irregular upper surface of crustal Layer 2. However, sediment cover is extremely variable, locally thickening to $0.4 \mathrm{sec}$ but rarely exceeding $0.1 \mathrm{sec}$ (Figures $7,16,17,26$ ). The very thin cover is usually a pelagic draping, and thicker cover commonly appears as hummocks centered within basement depressions. The Antarctic Circumpolar Current has effectively swept most of the topographic highs clear of pelagic sediment and transported it from the region, or concentrated it as hummocks in the "eye" of small topographically controlled current vortices (arrows, Figures 16, 26). Sediment ponding and laminated sediments generally are not observed.

\section{PALEOSEDIMENTATION PATTERNS}

The evolution of sedimentary processes in the Bellingshausen Basin can be deduced from three lines of evidence: (1) the tectonic evolution of the basin, which has exerted a primary control on sedimentation patterns, (2) upward changes in the detailed acoustic character of sediments in seismic profiles, and (3) drilling results. In the following discussion we attempt to interpret the Leg 35 drilling results, in conjunction with the profiler data, to synthesize basinwide paleosedimentation patterns. Our interpretations incorporate Herron and Tucholke's deductions concerning the tectonic evolution of the southeast Pacific crust (this volume).

As we noted earlier in this chapter, the Tula Fracture Zone roughly divides the ocean crust beneath the continental margin into two provinces, wherein crust northeast of the fracture has been subducted beneath Antarctica more recently than crust to the southwest. Two sites were drilled on either side of this fracture trend, and we discuss each of the crustal provinces and its two drill sites as a unit.

Drilling at Site 323 indicated a crustal age of late Cretaceous (Maestrictian), and the crustal elevation 

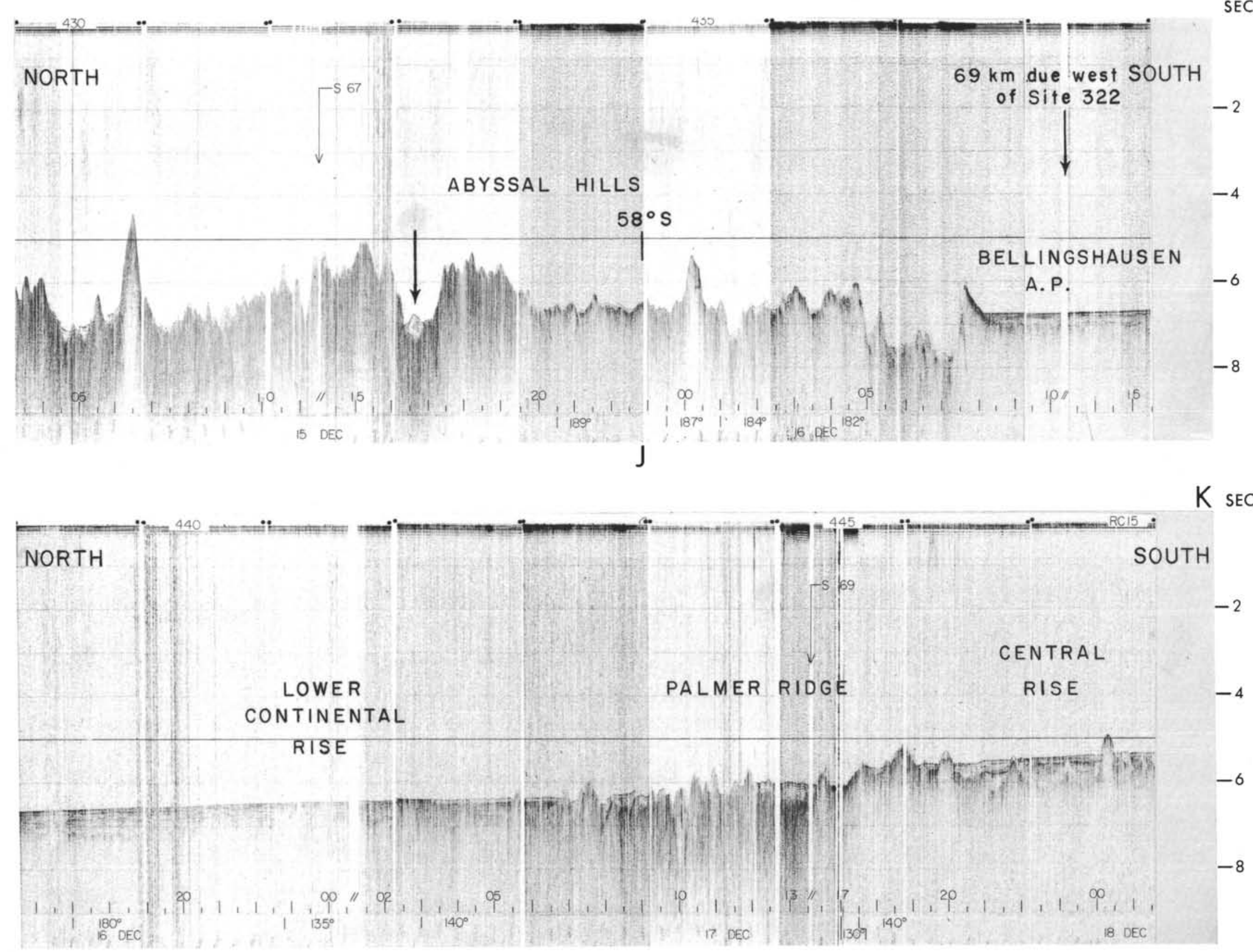


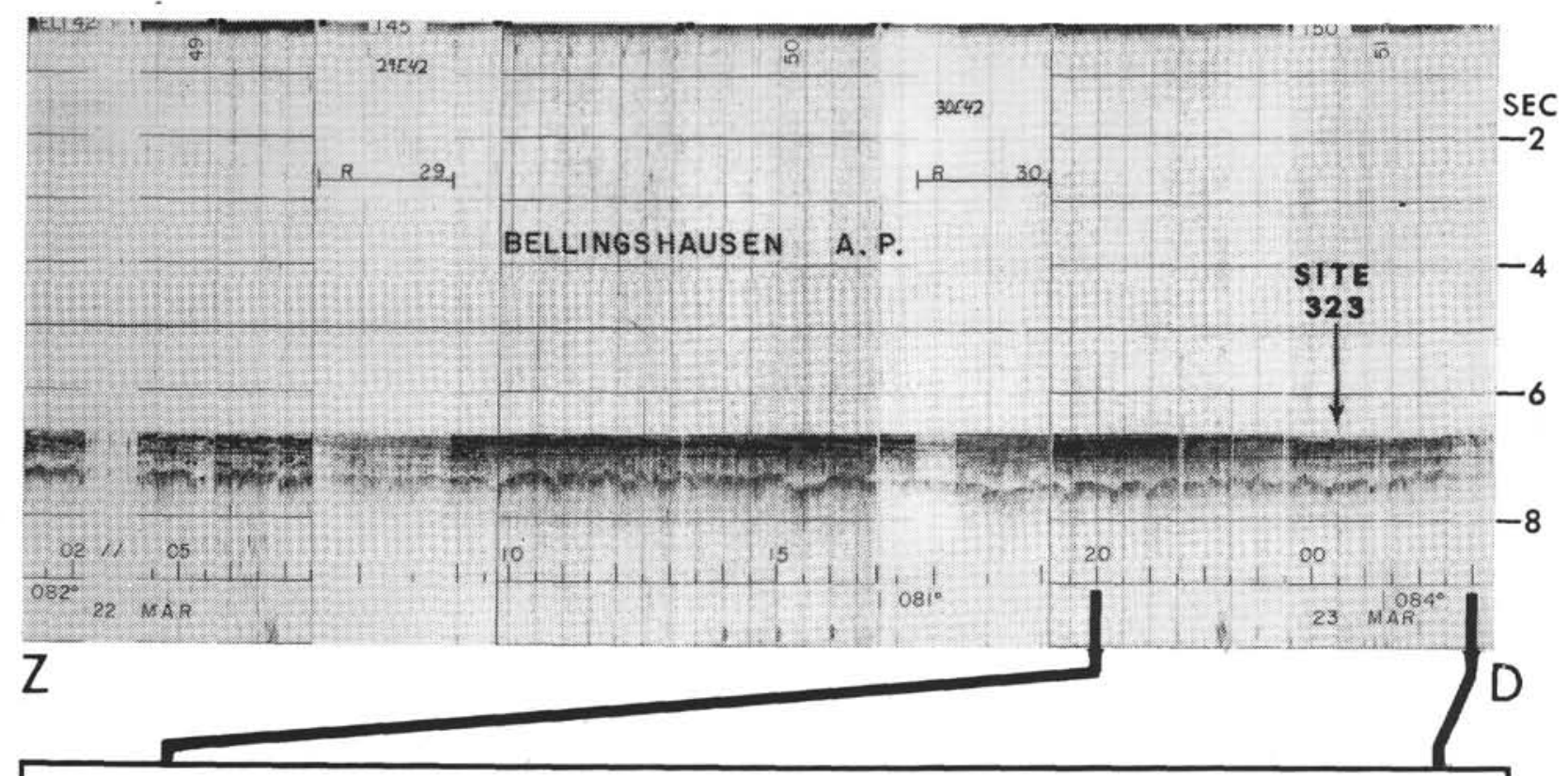

\section{ELTANIN 42}
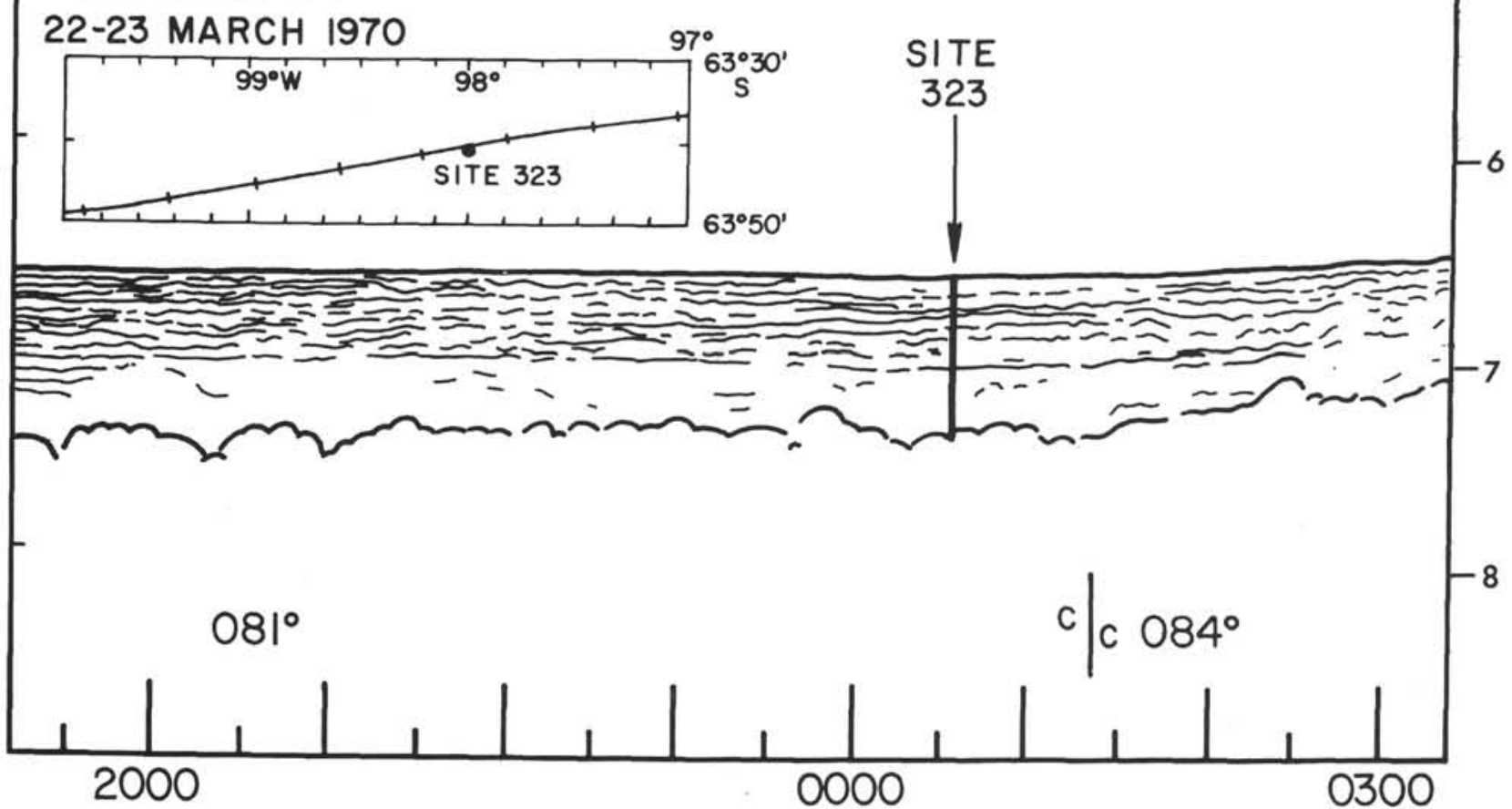

Figure 27. Eltanin 42 profile across Site 323 and interpretation. Location in Figure 11.

suggests an age of about 70 m.y. (Herron and Tucholke, this volume). Although these ages suggest that the crust originated at the Aluk Ridge at about anomaly 30 time, there is enough uncertainty in the ages that the crust could instead have formed at the Pacific-Antarctic Ridge before anomaly 32 time. The apparent extension of the Eltanin Fracture Zone eastward of Site 323 tends to support the second alternative. In either case, the Site 323 crust must have been isolated from terrigenous Antarctic sediments for a significant period of time, both because of its inital elevation as youthful sea floor and because of the interposing Aluk Ridge which was active no later than the end of the Cretaceous (anomaly 26,
Figure 1). Thus only pelagic sediments accumulated until at least anomaly 20 time (early Eocene), when the Aluk Ridge was subducted beneath the Antarctic margin and underthrusting apparently ceased. It probably took several million years more for a prograding wedge of terrigenous sediment to reach Site 323 at the northern edge of the basin. Subsequently, further seaward construction of the continental rise allowed deposition of increasingly proximal, coarser turbidites at the site.

The sedimentary record at Site 323 agrees with this interpretation. Brown pelagic clays accumulated above basalt until sometime in the (?) Oligocene to early 


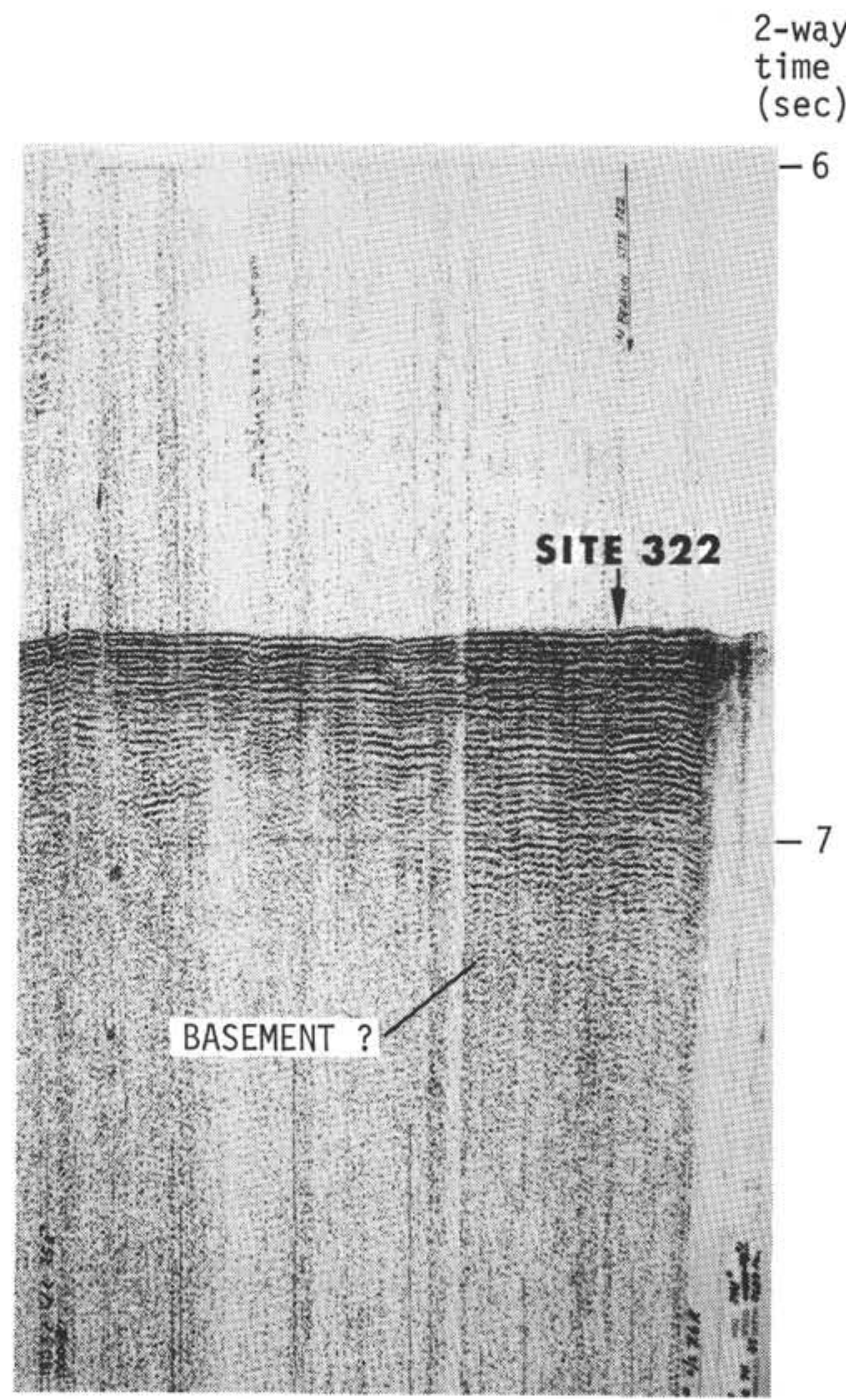

Figure 28. Glomar Challenger profile across Site 322.

Miocene (Core 14) when an influx of terrigenous clay and silty clay began, presumably as distal turbidite deposits. The terrigenous sediments at the site tend to coarsen upward in the sediment column, reflecting deposition from higher energy turbidity currents.
There is no recognizable reflecting horizon in the profiler records that correlates with the basal 62-meter interval of pelagic brown clays. At shallower depths, a prominent mid-sediment reflecting horizon correlating with lower Miocene cherts cored between 400 and 500 meters (Cores 8-10) is well developed only in the vicinity of Site 323 (Figure 27). This horizon cannot be correlated with adjacent basin reflectors, but similar strong reflecting horizons in the adjacent Eltanin Fracture Zone (Profile E. Figure 8) may also be diagenetic. The reflector at Site 323 represents the earliest occurrence of significant biogenic silica in the sediment column.

The reflectors observed above this horizon tend to be irregular and discontinuous, and reflectors in the shallowest 0.3 to $0.5 \mathrm{sec}$ of the adjacent abyssal plain sediments are similarly disturbed. One plausible explanation for this irregularity is that the sediment has been redistributed by bottom currents. Textures and compositional data also suggest current reworking of sediments in the interval above Core $10(500 \mathrm{~m})$ at Site 323. If the observed increase of siliceous organisms in this interval is a circulation-related phenomenon, then the combined evidence of biogenic silica distribution, sediment textures, and the acoustic record at Site 323 suggests that a significant increase in circum-Antarctic circulation occurred in the early Miocene. Drilling on DSDP Legs 28 and 29 suggested initiation of major flow, possibly part of a circumpolar current, between Australia and Antarctica as early as middle Oligocene (Kennett et al., 1974; Hayes and Frakes, 1975). However it is possible that shallow oceanographic barriers were present in the Drake Passage until the Miocene, thus suppressing deep current activity in the Bellingshausen Basin.

Site 324 was drilled landward of Site 323 on the lower continental rise. Magnetic anomalies east of this site suggest that the hole was drilled above oceanic crust which is at least as old as anomaly 26 (early Paleocene) and which was formed on the northwest side of the Aluk Ridge. Although we were able to drill only 218 meters into the sediment here, we can infer the character of deeper sediment from the probable tectonic evolution of the area and from seismic profiler records.

Like Site 323, the crust at Site 324 was isolated from terrigenous sediment until at least the early Eocene so

2-way
time

(sec)

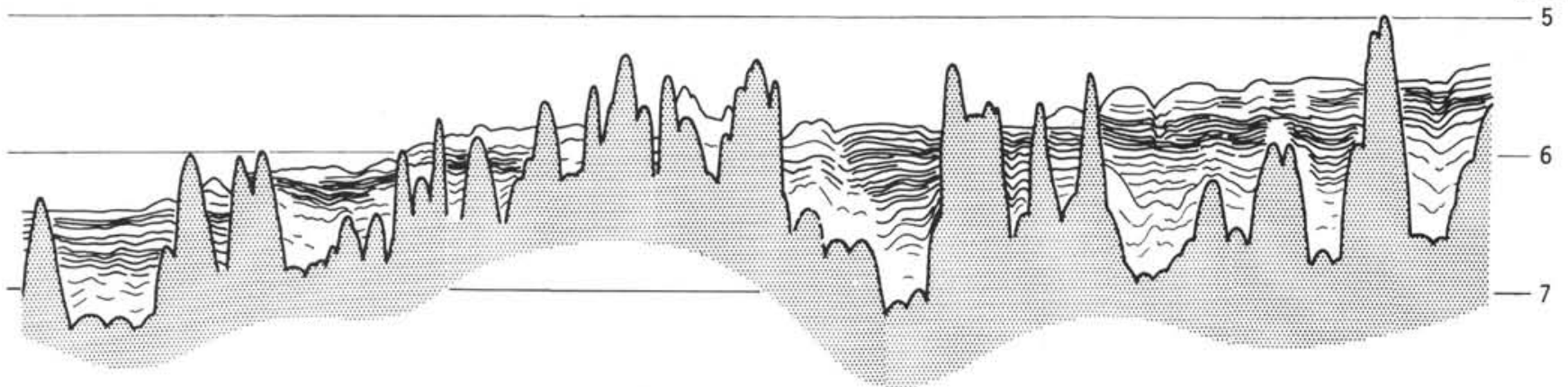

Figure 29. Interpretation of Eltanin 42 profile across Palmer Ridge. Location in Figure 17. 


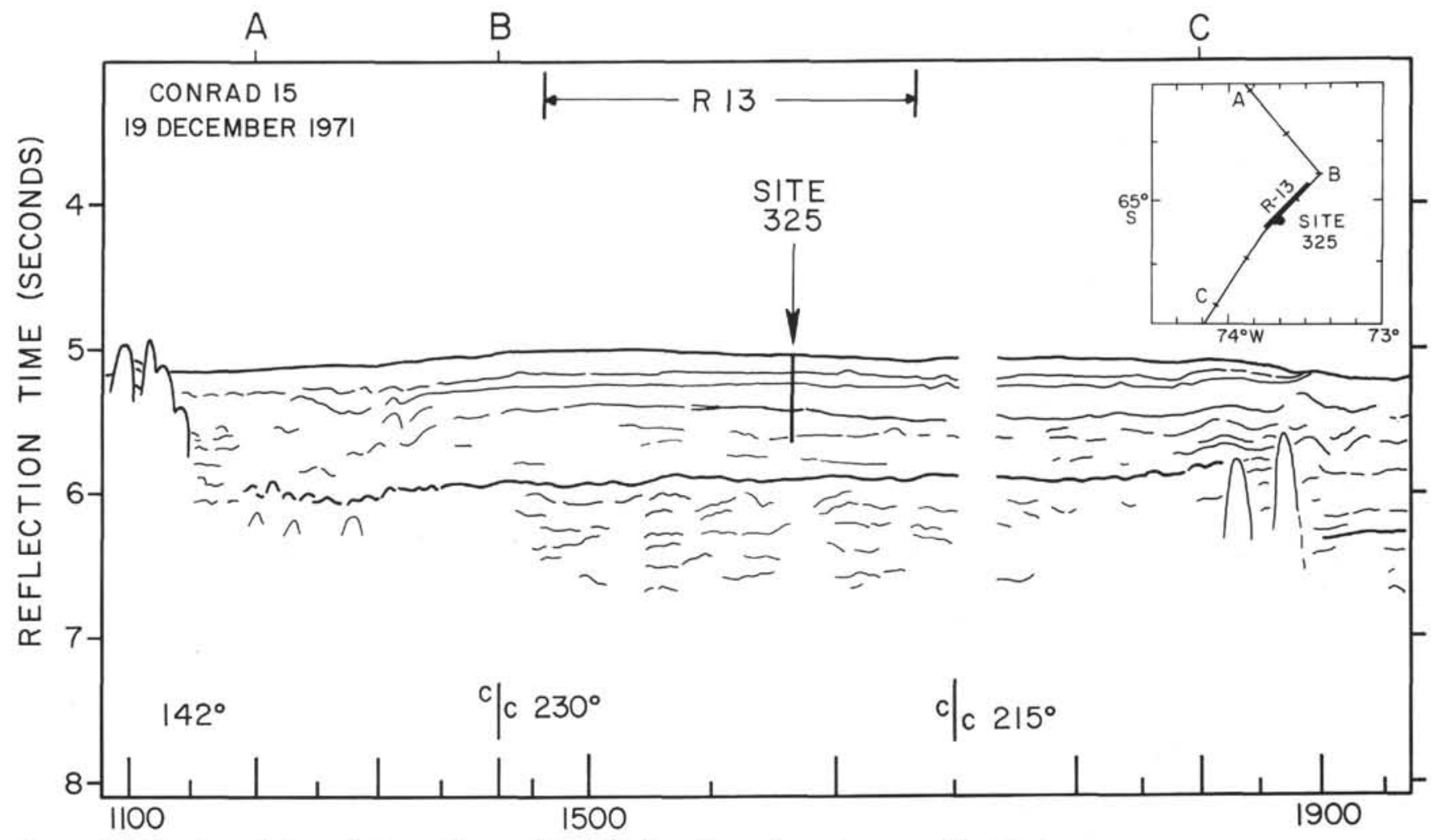

Figure 30. Tracing of Conrad 15 profile near Site 325. Location of sonobuoy run (R-13) shown.

that only pelagic sediment accumulated. Following subduction of the Aluk Ridge and stagnation of the trench, sediment shed from Antarctica eventually reached the area, first as fine-grained distal deposits and later as coarser, more proximal deposits. Isostatic recovery of the trench may have occurred within an interval as short as a million years (A. Watts, personal communication), thus allowing development of the continental rise as a seaward-thinning wedge of terrigenous detritus. Profiler data suggest that coarse detritus subsequently was deposited at Site 324 in a lower-continental-rise environment until the time of Horizon R (Figure 15).

The nonlaminated sediments cored above Horizon $\mathbf{R}$ at Site 324 represent the Pliocene seaward progradation of central-continental-rise deposition. Although the nonlaminated wedge resembles channel-levee sediments, it is possible that it has been deposited largely from bottom currents. Drilling data indicate that the sediments are homogeneous clays with thin $(<1 \mathrm{~cm})$, well-sorted beds of silt.

Northeast of the Tula Fracture Zone, Sites 322 and 325 have probably experienced depositional histories somewhat similar to those of Sites 323 and 324, but displaced forward in time because underthrusting along this margin ceased more recently (early to middle Miocene).

If the crust at Site 322 originated at the Aluk Ridge, its age should be close to early Paleocene (Figure 1). However, radiometric dates on the basalt cored here and micropaleontological analysis of the overlying sediment indicate that the basalt may be as young as (?) Oligocene to early Miocene (see Site 322 Report). Possible reasons for this discrepancy are discussed by Herron and Tucholke (this volume).
Magnetic anomaly patterns southeast of the site indicate that underthrusting continued along the continental margin northeast of the Tula Fracture Zone until well into the Miocene. Thus the marginal trench and Palmer Ridge should have blocked Site 322 from Antarctic terrigenous detritus until the late Miocene (Figures 4, 7, 17, 26). Cores recovered at this site, however, include only a 2-meter interval of brown pelagic clay above basalt; this in turn is overlain by a meter of fine terrigenous silty clay of early to middle Miocene age and by 40 meters of Miocene sandstone. The early influx of terrigenous sediment may reflect a source along the Antarctic margin southwest of the Tula Fracture Zone, as suggested by the tongue of sediment extending northeastward to this site (Figure 7). A slight basement rise southeast of Site 322 appears to have locally blocked sediment derived from the southeast until recently (Figure 17), but to the southwest we can observe deep layers progressively onlapping basement toward the site (Figure 25).

Profiler data in the vicinity of Site 322 indicate that the entire sedimentary column consists of acoustically laminated sediment which we interpret as turbidites derived from Antarctica. As at Site 323, reflectors in the profiler records tend to be irregular and discontinuous, possibly indicating sediment redistribution by bottom currents (Figure 28). The terrigenous sediments cored here consist of interlayered sands, silts, and clays; there are few primary structures in the cores, but those that are present are generally diagnostic of turbidites and support our turbidite interpretation of the acoustic laminae in profiler records. In addition, the terrigenous sediments recovered exhibit varying degrees of reworking by bottom currents. 


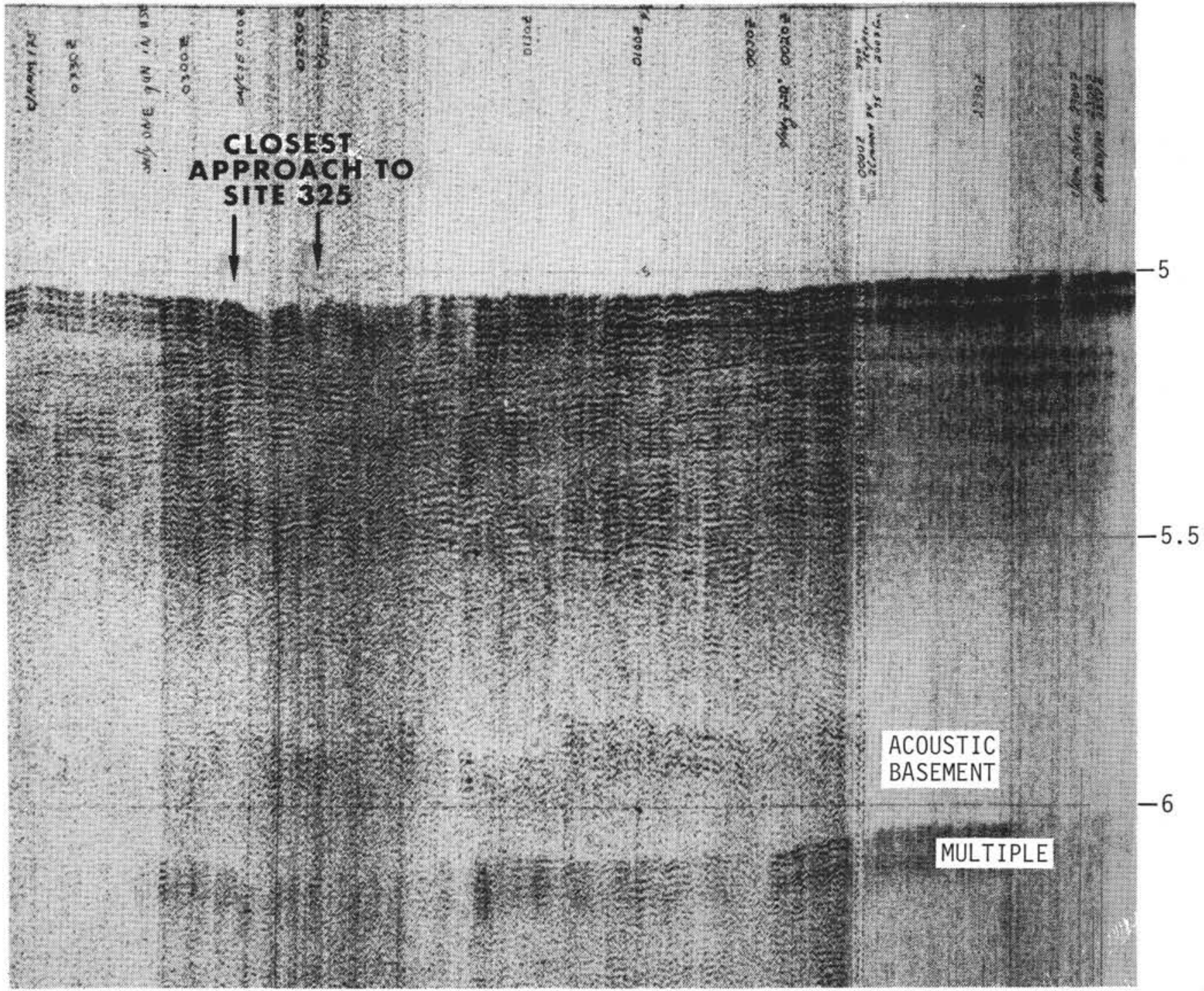

Figure 31. Glomar Challenger profile near Site 325.

The primary barrier against sediments reaching Site 322 is the Palmer Ridge (Figures 17, 26, 29). The northeasterly trend of this broad basement high and its position seaward of the defunct marginal trench suggest that it may have originated as a crustal upwarp seaward of the zone of underthrusting. The occurrence and formation of similar structural outer ridges along the North Pacific margin have been discussed by Watts and Talwani (1974). However, in this area we have the added complexity of a spreading ridge which has been subducted, and the buoyancy of the relatively youthful (Oligocene) crust of the Palmer Ridge may contribute to its present elevation.

Because crust comprising the Palmer Ridge formed on the northwest side of the Aluk Ridge, it must have been isolated from terrigenous debris during the history of underthrusting. This inference is confirmed by profiler data which show nonlaminated pelagic sediments draping over acoustic basement and ponding between peaks (Figure 29). This sediment in turn is covered unconformably by weakly laminated and laminated sediments which probably represent the influx of terrigenous debris following stagnation of the trench.

A variety of processes is responsible for the complex attitude and distribution of sediments on Palmer Ridge. Some of the laminated sediments emplaced by turbidity currents are ponded between peaks, and in a few places they form small moats around the obstacles, possibly reflecting local acceleration of turbid flows. Several small channels, first appearing about two-thirds of the way up the sedimentary column, appear to represent the seaward migration of sedimentation patterns characteristic of the central continental rise, and finely laminated levees have recently developed beside the channels. Some parts of the ridge still isolated from tur- 
bidity currents are covered by nonlaminated pelagic sediments which have been redistributed into irregular patterns by bottom currents.

Landward of the Palmer Ridge, Site 325 was drilled on crust which also was formed on the north side of the Aluk Ridge, and magnetic anomalies indicate a crustal age of late Oligocene (Figure 1). This site lies in the central-continental-rise province and the acoustic stratigraphy consists of well-laminated sediments overlying a weakly laminated interval (Figures 30, 31); a mid-sediment reflecting horizon is fairly well developed between these units. These sediments overlie unusually smooth acoustic basement (Horizon S). A sonobuoy recorded less than a kilometer from Site 325 on Conrad cruise 15 shows that Horizon $\mathrm{S}$ does not have velocities characteristic of basaltic basement and that basalt, with a velocity of $5.35 \mathrm{~km} / \mathrm{sec}$, lies about $0.14 \mathrm{sec}$ deeper (see Tucholke and Edgar, this volume).

Horizon S can be traced as an anomalously smooth horizon at about $6 \mathrm{sec}$ below the sea surface throughout the area landward of the Palmer Ridge, and it is interpreted as the surface of a sequence of high-velocity sediments ponded behind the ridge. The early sediments which began to fill and cover the stagnating trench were probably relatively coarse grained. If they also were cemented by calcite or silica, as was commonly observed in the cores of Site 325 above Horizon S, they could easily create the observed reflector. Below Horizon S, weak discontinuous reflectors probably indicate acoustic impedance contrasts in the material ponded between basalt peaks. Christensen et al. (1973) have observed that such high-velocity sediments can completely mask basalt in seismic records.

Sediment cored at Site 325 indicates that the reflectors above Horizon S result from impedance contrasts caused both by textural changes (interbedded fine- and coarse-grained sediment) and by diagenetic cementation. Our acoustic interpretation of this central-rise province attributes the acoustic laminae to the combined effects of turbidity currents and sediment redistribution by bottom currents, and the primary structures in the cored sediment substantiate this interpretation (see Site 325 Report). The mid-sediment reflector appears to correspond to calcite-cemented siltstone in Core 5, but it cannot be traced with confidence throughout the region; the reflector is seldom well defined, and it locally disappears. There are local suggestions that the overlying laminated sediments rest unconformably on the reflector or pinch out against it, but this effect is also observed at other acoustic-stratigraphic levels, and it probably results from local variability in turbidite/contourite deposition throughout the laminated interval.

\section{CONCLUSIONS}

Synthesis of acoustic information can be a valuable tool for prediction of paleosedimentation patterns and processes, especially when it is evaluated in terms of the morphology and tectonic framework of the basin and is controlled absolutely by drilling results at key locations. However, there are limitations to acoustic interpreta- tion, and some instances are summarized here for the Bellingshausen Basin.

1) We have interpreted the weak acoustic lamination of the most deeply buried sediments as a diminution of impedance contrasts caused by increased uniformity of physical properties in the consolidated sediments. Physical properties measurements on lithologically dissimilar, consolidated core samples support this interpretation. However, if drilling data were not available, it would be difficult to distinguish this effect from that of signal attenuation or of simple uniformity in sediment composition. In any case, the absence of acoustic reflectors in the deep sediments of the Bellingshausen Basin generally limits evaluation of early morphologic features and paleosedimentation processes, particularly in regard to the transition from pelagic to terrigenous deposition.

2) Although ascertaining the location, attitude, and pattern of acoustic intervals can be productive in the evaluation of processes of terrigenous sedimentation in the basin, it gives us virtually no clues to biogenic sedimentation except possibly in specialized instances such as the abyssal hills province. For this reason we have limited acoustic interpretation of biogenic sedimentation to areas with drill-hole control.

3) Interpretation of the synchroneity and cause of specific reflecting horizons must be approached with caution. Several prominent reflectors at Sites 323 and 325 were determined by drilling to correlate with cherts and calcite-cemented sediments. Acoustic records seldom imply the composition of these horizons, and local variations in sediment composition can strongly affect the chronostratigraphic level at which diagenetic cementation occurs.

Diagenesis also may have affected the acoustic signature of Horizon S beneath the continental rise. Furthermore, in the Bellingshausen Basin the complex tectonic control on paleosedimentation patterns has undoubtedly affected both the causative processes and timing of deposition of such wide-ranging reflectors as Horizon S, and it is likely that they are diachronous.

4) One of the most intriguing aspects in the study of circum-Antarctic profiler data is the search for evidence of glaciation. However, the well-developed acoustic lamination of most Bellingshausen Basin sediments confuses identification of specific horizons which might be attributed to massive influx of coarse detritus during a period of maximum glaciation. In the case of Horizon $\mathrm{R}$, however, we observe highly reflective patches of sediment lying beneath submarine channels and joined by a common reflector; this is the single instance where the acoustic characteristics may be reasonably matched to a period of intense turbidity-current activity and icerafting which results from extensive continental glaciation.

\section{ACKNOWLEDGMENTS}

We thank C.D. Hollister, C. Craddock, S. Eittreim, and C. Windisch for discussions and review of the manuscript. Lamont-Doherty data collection and processing were supported by the Office of Polar Programs, National Science Foundation Grant GA12825 (U.S.N.S. Eltanin), and by NSF Grant GA27281 and Office of Naval Research Contract 
N00014-67-A-108-0004 (R/V Robert Conrad). Sonobuoys used on these cruises were furnished by the Office of Naval Research. The senior author gratefully acknowledges support by a Lamont Doherty Postdoctoral Fellowship during preparation of this manuscript.

\section{REFERENCES}

Baker, P.E., Davies, T.G., and Roobol, M.J., 1969. Volcanic activity at Deception Island in 1967 and 1969: Nature, v. 224 , p. $553-560$.

Baraznagi, M. and Dorman, J., 1969. World seismicity map compiled from ESSA, Coast and Geodetic Survey, epicenter data, 1961-1967: Seism. Soc. Am. Bull., v. 59, p. $369-380$.

Barker, P.F., 1971. Magnetic lineations in the Scotia Sea. In Adie, R.J. (Ed.), Antarctic Geology and Geophysics: Oslo (Universitets-forlaget), p. 17-26.

Biscaye, P.E. and Eittreim, S.L., 1974. Temporal variations in benthic boundary layer phenomena; nepheloid layer, North American Basin. In Gibbs, R. (Ed.), Suspended Solids in Water: New York (Plenum Press), p. 227-260.

Christensen, N.I., Fountain, D.M., and Stewart, R.J., 1973. Oceanic crustal basement: a comparison of seismic properties of D.S.D.P. basalts and consolidated sediments: Marine Geol., v. 15, p. 215-226.

Ciesielski, P.F. and Weaver, F.M., 1974. Early Pliocene temperature changes in the Antarctic Seas: Geology, v. 2, p. 511-515.

Ewing, J.I., Ludwig, W.J., Ewing, M., and Eittreim, S.L., 1971. Structure of the Scotia Sea and Falkland Plateau: J. Geophys. Res., v. 76, p. 7118-7137.

Ewing, M., Ewing, J.I., Houtz, R.E., and Leyden, R., 1968. Sediment distribution in the Bellingshausen Basin. In Antarctic Oceanography, Symp., Sept. 13-16, 1966, Santiago, Chile: Cambridge (Scott Polar Res. inst.), p. 89-99.

Ewing, M., Houtz, R., and Ewing, J., 1969. South Pacific sediment distribution: J. Geophys. Res., v. 74, p. 2477-2493.

Ewing, M., Eittreim, S.L., Ewing, J.I., and Le Pichon, X. 1971. Sediment transport and distribution in the Argentine Basin. 3. Nepheloid layer and processes of sedimentation. In Ahrens, L.H., et al. (Eds.), Physics and chemistry of the earth: New York (Pergamon Press), p. 51-77.

Fox. P.J. and Heezen, B.C., 1968. Abyssal anti-dunes: Nature, v. 220 , p. $470-472$.

Frakes, L.A., 1971 USNS Eltanin core descriptions, cruises 32 to 45 (unpublished report): Antarctic Core Facility, Department of Geology, Florida State University.

Hayes, D.E. and Frakes, L.A., 1975. General synthesis-Deep Sea Drilling Project, Leg 28. In Hayes, D.E., Frakes, L.A., et al., Initial Reports of the Deep Sea Drilling Project, Volume 28: Washington (U.S. Government Printing Office), p. 919-942.

Heezen, B.C., Ewing, M., and Ericson, D.B., 1954. Reconnaissance survey of the abyssal plain south of Newfoundland: Deep-Sea Res., v. 2, p. 122-1-3.

Heezen, B.C., Hollister, C.D., and Ruddiman, W.F., 1966. Shaping of the continental rise by deep geostrophic contour currents: Science, v. 152 , p. 502-508.

Hollister, C.D. and Heezen, B.C., 1967. The floor of the Bellingshausen Sea. In Hersey, J.B. (Ed.), Deep-sea photography: Baltimore (John Hopkins Press), p. 177-189.

Hollister, C.D. and Heezen, B.C., 1972. Geological effects of ocean bottom currents: Western North Atlantic. In Gor- don, A.L. (Ed.), Studies in physical oceanography: New York (Gordon and Breach), v. 2, p. 37-66.

Hollister, C.D., Flood, R.D., Johnson, D.A., Lonsdale, P., and Southard, J.B., 1974. Abyssal furrows and hyperbolic echo traces on the Bahama Outer Ridge: Geology, v. 2, p. $395-400$

Houtz, R.E., 1974a. Continental margin of Antarctica: Pacific-Indian sectors. In Burk, C.A. and Drake, C.L. (Eds.), The geology of continental margins: New York (Springer-Verlag), p. 655-658.

1974b. Preliminary study of global sediment sound velocities from sonobuoy data. In Hampton, L. (Ed.), Physics of sound in marine sediments: New York (Plenum Publ.), p. 519-535.

Houtz, R.E., Ewing, J., and Buhl, P., 1970. Seismic data from sonobuoy stations in the Northern and Equatorial Pacific: J. Geophys. Res., v. 75 , p. 5093-5111.

Houtz, R.E., Ewing, M., Hayes, D., and Naini, B., 1973. Sediment isopachs in the Indian and Pacific Ocean sectors $\left(105^{\circ} \mathrm{E}\right.$ to $\left.70^{\circ} \mathrm{W}\right)$, Antarctic Map Folio Series, Folio 17-Sediments: Washington (Am. Geograph. Soc.), p. 912.

Jacobs, S.S., Bruckhausen, P.M., Rosselot, F.L., Gordon, A.L., Amos, A.F., and Belliard, M., 1972. ELTANIN reports: Cruises 37-39, 1969; 42-46, 1970: Lamont-Doherty Geological Observatory Tech. Rept. 1-CU-1-72.

Jones, E.J.W., Ewing, M., Ewing, J.I., and Eittreim, S.L., 1970. Influences of Norwegian Sea overflow water on sedimentation in the northern North Atlantic and Labrador Sea: J. Geophys. Res., v. 75, p. 1655-1680.

Kennett, J.P., Houtz, R.E., Andrews, P.B., Edwards, A.R., Gostin, V.A., Hajos, M., Hampton, M.A., Jenkins, D.G., Margolis, S.V., Ovenshine, A.T., Perch-Nielsen, K., 1974. Development of the circum-Antarctic current: Science, v. 186, p. 144-147.

Mammerickx, J., Smith, S.M., Taylor, I.L., and Chase, T.E., 1974a. Bathymetry of the South Pacific: Scripps Inst. Oceanogr., IMR Tech, Rept. 53A, Chart no. 20, 1st. ed., March 1974.

1974b. Bathymetry of the South Pacific: Scripps Inst. Oceanogr., IMR Tech, Rept. 54A, Sheet 21B, 1st ed., April 1974.

Matthews, D.J., 1939. Tables of the velocity of sound in pure water and sea water for use in echo sounding and echo ranging: London (admiralty Hydrographic Dept.).

Reid, J.L. and Nowlin, W.D., 1971. Transport of water through the Drake Passage: Deep-Sea Res., v. 18, p. 51-64.

Roberts, D.G., Hogg, N.G., Bishop, D.G., and Flewellen, C.G., 1974. Sediment distribution around moated seamounts in Rockall Trough: Deep-Sea Res., v. 21, p. $175-$ 184.

Scientific Staff, 1974. Deep Sea Drilling Project, Leg 37-the volcanic layer: Geotimes, p. 16-18.

Sclater, J.G., Anderson, R.N., and Bell, M.L., 1971. Elevation of ridges and evolution of the central eastern Pacific: J. Geophys. Res., v. 76, p. 7888-7915.

Talwani, M., Windisch, C.C., and Langseth, M.G., Jr., 1971. Reykjanes Ridge crest: a detailed geophysical study: J. Geophys. Res., v. 76, p. 473-517.

Tucholke, B.E. and Ewing, J.I., 1974. Bathymetry and sediment geometry of the greater Antilles Outer Ridge and vicinity: Geol. Soc. Am. Bull., v. 85, p. 1789-1802.

Watts, A.B. and Talwani, M., 1974. Gravity anomalies seaward of deep-sea trenches and their tectonic implications: Geophys. J.Roy. Astron. Soc., v. 36, p. 57-90. 